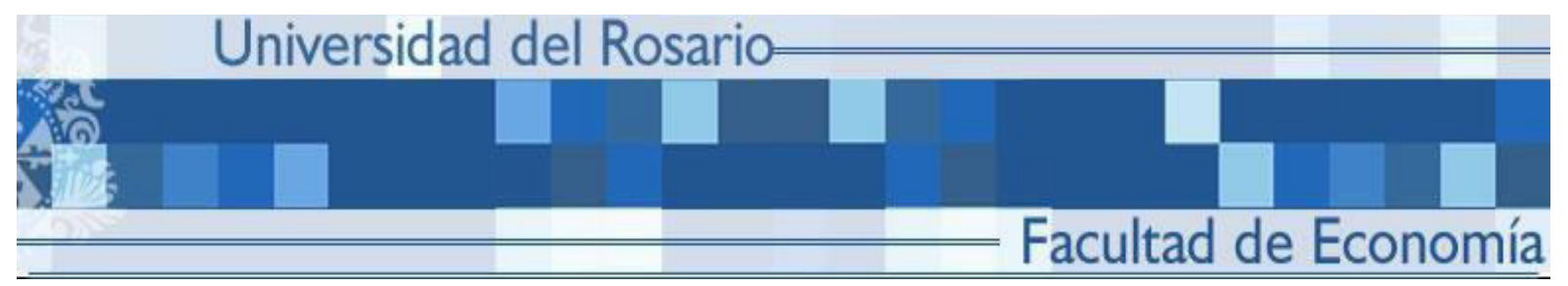

Losing Your Dictator: Firms During Political Transition

Felipe González

Mounu Prem

SERIE DOCUMENTOS DE TRABAJO

No. 212

Enero de 2018 


\title{
Losing Your Dictator: Firms During Political Transition*
}

\author{
Felipe González $^{\dagger} \quad$ Mounu Prem ${ }^{\ddagger}$
}

\begin{abstract}
Can firms transfer distortions across political regimes? To answer this question, we use a novel dataset and a network analysis to study firms during Chile's transition to democracy. We find that firms with links to the dictatorship were relatively unproductive before the transition, increased their productive capacity, enjoyed higher profits, and obtained more loans from state-owned banks during political transition. We test for different explanations and provide suggestive evidence consistent with strategic behavior aiming to improve their market position in democracy. These results suggests that distortions can be transferred across political regimes.
\end{abstract}

Keywords: transition, distortions, firms, networks

* October 2017. We would like to thank Shai Bernstein, Nick Bloom, Arun Chandrasekhar, Emanuele Colonnelli, Loreto Cox, Ernesto Dal Bó, Dave Donaldson, Pascaline Dupas, Liran Einav, Fred Finan, Solomon Hsiang, Guido Imbens, Borja Larrain, Jeremy Magruder, Guillermo Marshall, Edward Miguel, Melanie Morten, Petra Moser, Suresh Naidu, Josh Rauh, Andrés Rodríguez-Clare, José Tessada, Francisco Urzúa, Alonso Villacorta, and seminar participants at UC Berkeley, PUC-Chile, Stanford, Universidad de Chile, Universidad de Los Andes in Chile, Universidad de Los Andes in Colombia, Universidad Javeriana, Universidad del Rosario, the 2014 Annual Meeting of the Chilean Economic Society, and the 2015 Development and Political Economy Conference for comments and suggestions. We are grateful to the Center for Effective Global Action, Stanford Center for International Development, and the Economic History Association for financial support.

†Pontificia Universidad Católica de Chile, Instituto de Economía. Contact email: fagonza4@uc.cl

$\ddagger$ Universidad del Rosario, Department of Economics. 


\section{Introduction}

Political transitions are ubiquitous and are associated with significant changes in the economy, but little is known about the behavior of key economic actors such as firms during these times. ${ }^{1}$ A better understanding of the behavior of firms can help us to unbundle the black box behind the economic effects of political transitions. In addition, this knowledge is also crucial to understand the sustainability of democracy, a result which, as the Arab Spring has reminded us recently, is far from guaranteed.

Distortions in the allocation of resources across firms are an important source of economic inefficiency (Hsieh and Klenow, 2009) and politics is at the heart of this issue. Indeed, scholars have long argued that firms with links to the state benefit from a number of distortions such as, for example, preferential relationship with state-owned banks. ${ }^{2}$ The anticipation that these distortions will disappear if there is a regime change could lead firms to "prepare" for the new state of the world. If firms successfully prepare, this anticipation might affect markets even well after the regime change. Firms would be able to transfer distortions across political regimes, possibly limiting the benefits of a democratization and the market changes it creates. Observing how firms "prepare" to better position themselves under the new regime is, however, typically difficult.

Can firms transfer distortions across political regimes? This paper focuses on Chile's transition to democracy to study how firms with links to the Pinochet dictatorship (19731990) prepared for a future democratic period. Using a novel dataset of balance sheets, firm-level annual reports, and a network analysis of board members who worked for Pinochet, we find that firms with links to the dictatorship were relatively unproductive before the transition (1973-1988), increased their productive capacity, enjoyed higher profits, and obtained more loans from state-owned banks during political transition (19881990), and had better market outcomes in democracy (1990s). We discuss a number of po-

\footnotetext{
${ }^{1}$ There have been four transitions to democracy per year in the last 25 years (Figure A.1). A large literature studies the effects of political regimes on economic variables. See Acemoglu et al. (2017b) for a recent discussion of the literature and Papaioannou and Siourounis (2008b) for an empirical assessment of democratization theories.

${ }^{2}$ See Fisman (2001), Khwaja and Mian (2005), Faccio (2006), Faccio et al. (2006), Jayachandran (2006), Claessens et al. (2008), Ferguson and Voth (2008), Blanes i Vidal et al. (2012), Cingano and Pinotti (2013), and Colonnelli and Prem (2017), among others.
} 
tential explanations for these findings and provide suggestive evidence consistent with a strategic behavior of firms aiming to improve their market position in democracy. These results constitute direct evidence of distortions being transferred across political regimes.

Chile's transition to democracy provides a unique opportunity to measure and study the interactions between a dictatorship and firms. Vast amounts of (previously unexploited) information exists about firms operating during and after the dictatorship led by Augusto Pinochet (1973-1990). The existence of records with information about people who worked for Pinochet assures that interactions between the state and firms are measurable. In addition, the timing of this political transition gives us an opportunity to measure firm behavior after a democratization announcement but before the new democratically elected government took office. After fifteen years in power, Augusto Pinochet called for elections in 1988, where he would run as candidate to transform his autocratic regime into a democratic one for the next eight years. Contrary to everyone's expectations, Pinochet not only lost the election, but also acknowledged his defeat. This election, known as the "1988 plebiscite," marked the beginning of Chile's transition to democracy. The plebiscite's outcome changed the following years from a Pinochet regime to a democracy. We take advantage of these features to study how firms operating in dictatorship moved towards the new democratic era.

Our analysis uses a novel dataset of publicly listed firms observed between 1985 and 1994. We constructed these data by hand-collecting firm-level information from two different administrative sources: quarterly balance sheets and firm-level annual reports. Both data were stored in Chile's stock market regulatory agency and have been previously unused. In the former we observe assets and its subcategories, debt and its subcategories, and profits. In the latter we observe firm-bank relationships and the identity of board members. To identify firms with links to the regime, we conduct a network analysis of board members that worked for Pinochet before 1988, a process which results in the identification of firms with direct or indirect links to the regime. The usage of direct and indirect links is a relevant and new dimension of our empirical approach.

To motivate our analysis of firms during political transition, we hand-collected daily stock prices of firms in our data to investigate how financial investors reacted to the plebiscite. We document that firms with direct or indirect links to Pinochet suffered a 
substantial decrease in their stock value in the days that followed. Although decreases in stock prices of connected firms after negative political events have been documented before, the patterns among firms indirect links are novel and suggest the existence of more complex political networks than previously thought.

The core of our analysis combines our network of firms with direct, indirect, and no links to Pinochet with a differences-in-differences framework across three political periods, i.e. dictatorship (four years), transition (one-and-a-half years), and democracy (five years). Exploiting within firm variation over time, we find that firms with direct links increased their productive capacity by 0.4 standard deviations $(\sigma)$ and enjoyed $0.2 \sigma$ higher profits during political transition, with no significant changes in either productivity or labor. In the credit market, we find that firms with direct links obtained substantially more loans from state-owned banks during political transition. Importantly, all these results account for any effects the transition might have had across industries (and other observable variables) and are robust to a wide range of empirical exercises, including placebos that exploit the attempted murder of Pinochet in dictatorship and elections in democracy.

Why did firms with direct links to the regime increase their productive capacity, enjoyed higher profits, and obtained more loans from state-owned banks during political transition? The last part of our paper explores four different explanations: the role of political and economic uncertainty, a potential strategic behavior of firms aiming to improve their market position in democracy, the regime's potential strategic placement of individuals across firms, and wealth transfers from the regime to firm owners. Using a collection of additional empirical evidence and contemporaneous accounts that include narrative evidence from businessmen, we conclude that the evidence is most consistent with a strategic behavior of firms aiming to improve their market position.

Our work is closely related to the empirical literature studying the legacies of nondemocracies. The empirical literature documenting short-term persistence of economic and political distortions across regimes is a relatively new area of research and has focused mostly on local politicians. For example, Martínez Bravo (2014) shows that appointed officials that persisted in power after Indonesia's transition to democracy are associated to significant economic and political distortions. In the same context, Martínez Bravo et al. (2018) show that mayors who persisted in power experience worse gover- 
nance outcomes, highlighting the costs associated to slow transitions. We contribute to this literature by examining the persistence of economic distortions associated to firms during political transition, thus suggesting a new dimension of inefficiency arising from slow transitions (see Roland 2002 for a survey).

This paper also contributes to the empirical literature studying the economic effects of political transitions. Estimates of the effect of democracy on economic growth go back to at least the beginning of the 1990s and have been the focus of contentious debates. Acemoglu et al. (2017b) provide the most recent empirical analysis and show significant positive effects of democratizations on economic growth in the long-run. ${ }^{3}$ Our results suggest that the short-run effects of democratizations may be at least partially explained by a transfer of distortions from non-democratic times. In this sense, we interpret the persistence of distortions as a potential constraint to the effects of democratizations. ${ }^{4}$

The next section discusses the relevant aspects of the Pinochet regime, firms, and Chile's transition to democracy. Section 3 presents the data construction process, descriptive statistics, and motivating evidence from the stock market. Section 4 presents our main results, robustness checks, and a discussion about the importance of network links and the plebiscite. Section 5 discusses and presents evidence for mechanisms that can potentially explain our results. Section 6 concludes.

\section{Chile's transition to democracy}

The dictatorship led by General Augusto Pinochet in Chile began after a coup d'état against democratically elected socialist Salvador Allende on September 1973. Following the coup, Pinochet was part of a military junta that ruled the country until June 1974. After consolidating his power at the junta, Pinochet ruled the country for the next seventeen years. We can divide the Pinochet dictatorship in three periods: installation and repression (1973-75), implementation of radical economic policies (1976-82), and imple-

\footnotetext{
${ }^{3}$ See also Barro (1996), Tavares and Wacziarg (2001), Rodrik and Wacziarg (2005), Persson and Tabellini (2006), Papaioannou and Siourounis (2008a), Murtin and Wacziarg (2014) among many others. Doucouliagos and Ulubasoglu (2008) provide a meta-analysis of the literature.

${ }^{4}$ Our results also speak to a theoretical literature studying the persistence of economic power across political regimes (e.g. Acemoglu 2008, Acemoglu and Robinson 2008, and Acemoglu et al. 2011).
} 
mentation of pragmatic policies (1983-89). Our analysis focuses in the last period.

\subsection{Firms and the Pinochet regime}

We now briefly discuss the history of the relations between firms and the Pinochet regime. Although empirical work studying the practices of firms during this period is limited (Ossandón and Tironi, 2013), historical work documenting the relationship between firms and the regime is abundant. Relying on this research we argue that firm-state relations in the 1980s (our period of study) had their origins in (1) the preexisting links between advisors to the regime and the business world, and (2) the privatization program implemented in the 1970s and 1980s.

After the 1973 coup, the right-wing coalition saw an opportunity to pursue their economic program and persuaded the regime to implement market-based policies and to change the institutional framework (Cavallo et al., 2011). The regime was advised by two groups of individuals. The former group was composed by technocrats trained as economists at the University of Chicago - popularly known as "Chicago Boys" - who had developed an economic program for the right-wing candidate at the 1970 presidential election (Silva, 1991). The majority of these economists studied business at leading universities in Chile and had close connections to the business world (Silva, 1996). The latter group of advisors was in charge of designing and implementing the legal framework that was to be used by the regime (Huneeus, 2000). The majority of advisors were formally or informally associated to the right-wing coalition and had therefore close links to the business world.

In addition to the links between advisors and the business world, individuals who worked for the regime acquired control of firms in the context of a privatization program, probably one of Pinochet's most controversial policies. ${ }^{5}$ Individuals close to Pinochet started working as board members in firms that were privatized by the regime. Perhaps the most famous case is Pinochet's former son-in-law, Julio Ponce Lerou, who worked for the regime and became board member of the Chemical and Mining Society of Chile during its privatization process. Ponce Lerou represents one of the links between firms

\footnotetext{
${ }^{5}$ The controversy relies on the fact that people linked to the regime acquired firms at lower-than-market prices, effectively transferring wealth from the State to the private world (Mönckeberg, 2015).
} 
and the regime in our empirical analysis. ${ }^{6}$

\subsection{Democratization by election at the "1988 plebiscite"}

Pinochet called for elections in 1988 in which he would run as the only candidate, a Yes/No election known as the "1988 plebiscite" that took place on October 5th. Pinochet's goal was to internationally validate his regime and become president of Chile for the period 1988-1996. However, he did not accomplish his goal. In an election in which more than 90 percent of the voting-age population registered to vote, 56 percent rejected Pinochet's continuation. ${ }^{7}$ Then, in December of 1989, a presidential election with candidates from all parties took place, an election in which Pinochet could not run. As expected, the opposition won, and the new democratically elected president Patricio Aylwin took office in March of 1990. Between the plebiscite and the arrival of the new government, seventeen months transpired in which firms could have prepared for the new economic environment. This "transition" period is crucial in our analysis.

Pinochet's defeat at the plebiscite was unexpected for several reasons. First, there was no legal institution in charge of regulating the election. Second, previous surveys did not state a clear prediction (Cauce, 1988). Third, most people believed that Pinochet was not going to acknowledge a negative result. ${ }^{8}$ And fourth, on election day, most preliminary results showed that Pinochet was winning, and the opposition's victory was only recognized on October 6 at around 2 a.m. (Méndez et al., 1988; Engel and Venetoulias, 1992). In addition to this historical evidence, section 3.2 provides empirical evidence for the unexpectedness of the plebiscite's outcome by analyzing stock market returns of firms with and without links to the Pinochet dictatorship.

\footnotetext{
${ }^{6}$ Importantly, not all privatized firms were linked to Pinochet and not all firms linked to Pinochet were privatized. Thus, we can account for the effect of privatizations and differentiate it from the effect of links to Pinochet.

${ }^{7}$ More details about this election in Hirmas (1993), Boas (2015), and González and Prem (2017).

${ }^{8}$ According to declassified documents posted by the U.S. National Security Archive, Pinochet stated, "I'm not leaving power, no matter what." Different political forces (including the navy) pushed him to finally accept the result (Huneeus, 2006).
} 


\subsection{The credit market during political transition}

Three state-owned banks operated during our period of analysis: the Bank of the State, the Central Bank, and the Production Development Corporation. The Bank of the State granted 83 percent of loans from state-owned banks between 1988 and 1990 (see section 3). Executives at these banks were directly appointed by Pinochet and were in charge of the review and approval of loan petitions (Law No. 2079, enacted in 1978).

The President of the Bank of the State during the transition period was Alvaro Bardón, former President of the Central Bank (1977-81), Undersecretary of Finance (1982), and member of the Chicago Boys. Bardón was appointed president one month after the plebiscite (November 7, 1988) and remained in this position until the last week of the regime. This appointment has been the focus of controversy due to the bank's financial operations during the transition. The controversy lies on the privatization of El MerCurio and La Tercera (the two largest newspapers), bankrupted by the time of the transition. These newspapers were bailed out after the 1982 financial crisis and, as a consequence, were heavily indebted to the Bank of the State. These debts meant that the opposition party could have owned a significant part of the written media after taking office in 1990. To prevent this scenario, Bardón used debt swaps to transfer the ownership of newspapers to firms with links to Pinochet. These financial operations were implemented between November 1989 and March 1990 and, because of significant underpricing, cost the Bank of the State approximately 26 million USD (Leon-Dermota, 2003). ${ }^{9}$

This "newspapers case" exemplifies how the Pinochet regime used state-owned banks to gain an advantage during political transition. Leon-Dermota (2003, p. 143) puts it succinctly: "The connection between El Mercurio and the military regime facilitated access to credit that was used to invest and gain an advantage over competitors."

\footnotetext{
${ }^{9}$ Price Waterhouse was in charge of estimating this value. Bardón and his team were investigated for state fraud in 1991. In a controversial ruling, the Supreme Court decided to exonerate them. Leon-Dermota (2003) argues that this exoneration is an example of Pinochet's power in the new democratic era.
} 


\section{Empirical framework}

This section begins by describing the data construction process, including the method to identify the network of firms related to the Pinochet regime. Then, we present evidence from the stock market to motivate the study of firms. Finally, we present our empirical strategy to study firms during political transition.

\subsection{Data construction}

We constructed a dataset of firms listed in the Chilean stock market. Our main analysis uses 118 firms observed annually or quarterly between 1985 and 1994. The analysis starts in 1985 because of missing data in previous years. We collected firm-level information from two sources. First, we used quarterly balance sheets gathered by the stock market regulatory agency. ${ }^{10}$ Second, we digitized annual reports, required by law and audited by international companies. ${ }^{11}$ From these reports, we hand-collected firms outstanding borrowing from banks, bond and equity issuance, number of workers, year of foundation, and information about exports. We converted all variables to 1998 Chilean pesos using the consumer price index of the Central Bank of Chile.

The first part of our analysis studies investment in physical capital, profits, workers, and productivity. Similar to Banerjee and Duflo (2014), we define investment as the logarithmic change in land, machinery, and buildings. Profits are defined as earnings before interests, taxes, and depreciation. We estimated revenue productivity using Olley and Pakes (1996) procedure. We also used Hsieh and Klenow (2009) methodology to construct two misallocation measures, capital and output wedges. To handle outliers, we winsorized all variables at 2.5 percent of the empirical distribution. In addition, we constructed an indicator for exporting firms, an indicator for firms privatized by Pinochet, and existing business groups in 1987. The regime privatized 40 firms in our data, and

\footnotetext{
${ }^{10}$ Chile's regulatory agency is called Superintendencia de Valores y Seguros. The US equivalent is the Securities and Exchange Commission.

${ }^{11}$ We focus on 118 firms due to availability of reports. Every time regressions employ less than 118 firms is simply because of missing data in these annual reports.
} 
32 firms were part of nine different business groups. ${ }^{12}$ The second part of our analysis studies the credit market by analyzing firms outstanding borrowing from state-owned and other banks over time. We classified all firms in two-digit industries following the classification of United Nations (2008).

We constructed the network of firms related to Pinochet using the name of board members in the 1987 annual reports. In particular, we performed a Google search of all board members and classified them as linked to the regime if she worked for Pinochet before 1988 or was a member of Pinochet's close family. ${ }^{13}$ We found that approximately 10 percent of board positions were connected. We say a firm had a link to the regime if at least one board member worked for Pinochet. Besides direct (first degree) links, we say a firm had an indirect (second degree) link to the regime if none of its directors worked for Pinochet but at least one worked for a firm with a link. Several papers have shown that these "interlocking directors" affect firm outcomes through an information mechanism (e.g., Khwaja et al. 2011, Patnam 2013, and Fracassi 2016). Overall, we found that 43 firms had a direct link to Pinochet, 33 firms had an indirect link, and 42 were unconnected. Figure 1 presents this network of firms graphically. ${ }^{14}$

Table 1 presents descriptive statistics for the dictatorship period by type of link. Firms linked to the dictatorship were larger and older, more likely to have been exporters, privatized by the regime, and part of a business group. These firms were also less productive and accrued more debt from banks. Differences between firms with direct and indirect links are similar but smaller. In addition, the misallocation wedges reveal that connected firms benefited from cheaper access to credit and higher subsidies. Firms with links also had more access to credit and were less productive. These differences tend to be larger for firms with direct links and are similar when we use within industry comparisons.

\footnotetext{
${ }^{12}$ We identified privatized firms using data from a commission in charge of investigating privatizations. More information can be found in CEME (2004). We identified business groups using the official document Circular N. 766 produced by the stock market regulatory agency.

${ }^{13}$ Other papers have classified individuals as politically connected in a similar way (e.g., Fisman 2001, Bertrand et al. 2007, Acemoglu et al. 2017a, 2016). More details in Appendix B. Importantly, to construct this network we used the universe of board members and firms, both of which are fortunately available in complementary datasets.

${ }^{14}$ The distinction between direct and indirect links is novel, it does not drive our results, and increases the precision of our estimates. Nevertheless, we present results using only direct links to facilitate comparison with the literature. Table A.1 presents an example of a firm with a direct link and Table A.2 presents the number of firms per link type and industry.
} 


\subsection{The stock market}

The stock market reflects the knowledge of financial investors about current and future events and, therefore, it can provide valuable information about the contemporaneous perception of events. To estimate the effect of the plebiscite on the stock market we combine our network analysis with daily stock market prices we hand-collected from contemporary newspaper El Mercurio, publicly available at Chile's National Library. ${ }^{15}$ To account for unobserved variables affecting stock returns across firms we utilize "abnormal returns," i.e. the difference between actual returns and expected (business-as-usual) returns. We measure abnormal returns by restricting attention to firms that were traded four months before October 1988, reducing our data to 80 firms.

We present results graphically. Figure 2 reveals a significant drop in abnormal returns of firms linked to the Pinochet regime. This drop corresponds to a decrease of three standard deviations and is similar for firms with direct (first degree) and indirect (second degree) links. We confirmed that this drop in stock returns was unique to the plebiscite by studying abnormal returns around other important political events (Figure A.3). We interpret these patterns in the stock market as evidence that the outcome of the plebiscite was unexpected and as validation of our identification of the network of firms. ${ }^{16}$ These findings serve as motivation to study firms during political transition.

\subsection{Empirical strategy}

How did firms linked to the regime react to Pinochet's defeat at the plebiscite? Our econometric strategy exploits within firm variation, the plebiscite's outcome as an exogenous democratization announcement, and our network analysis of firms, resulting in a differences-in-differences with three time periods and three types of firms. As firms were not randomly linked to the regime, we perform a variety of exercises to show that results are explained by networks and the plebiscite and not other variables.

\footnotetext{
${ }^{15}$ Girardi and Bowles (2017) use the same data to estimate the effect of Allende's election in 1970 and Pinochet's coup in 1973 on the Santiago stock market. In terms of magnitude, the "NO" victory in the 1988 plebiscite is the largest drop in the history of the Santiago stock market.

${ }^{16}$ In contrast, the victory of the opposition at the 1989 presidential election was expected and did not cause significant changes in the stock market (Figure A.3-C). Table A.3 presents regression estimates.
} 
The main regression equation we estimate is:

$$
Y_{i j k t}=\beta_{T}\left(P_{i} \cdot T_{t}\right)+\gamma_{T}\left(p_{i} \cdot T_{t}\right)+\psi_{k t}+\xi_{i}+\lambda_{t}+\varepsilon_{i j k t}
$$

where $Y_{i j k t}$ is the outcome of firm $i$-part of business group $j$ and operating in industry $k-$ in period $t$. The outcomes in the first part of our analysis are investment, number of workers, productivity, and profits. The indicators $P_{i}$ and $p_{i}$ are indicators for firms with (respectively) direct or indirect links in 1987, mutually exclusive categories. Figure 3 presents the time series for outcome variables by link type and shows similar trends across groups before 1988. The vector $T_{t}$ contains indicators for the transition and the democracy periods, with dictatorship as the omitted category. The vectors of parameters $\beta_{T}=\left(\beta_{\text {tran }} \beta_{\text {dem }}\right)^{\prime}$ and $\gamma_{T}=\left(\begin{array}{ll}\gamma_{\text {tran }} & \gamma_{\text {dem }}\end{array}\right)^{\prime}$ contain the coefficients of interest, with $\beta_{\text {tran }}$ and $\gamma_{\text {tran }}$ capturing differences in firm behavior during political transition. The vector $\psi_{k t}$ captures industry unobservable shocks after the plebiscite, and $\xi_{i}$ and $\lambda_{t}$ represent firm and time fixed effects. Finally, $\varepsilon_{i j k t}$ is an error term clustered at the business group level. ${ }^{17}$

We also present results using three variations of equation (1). To explicitly show the importance of the network analysis, the first variation classifies firms with indirect links as unconnected firms. The second variation of equation (1) omits $\psi_{k t}$. When compared to our main regression, this specification shows the effect of industry shocks on our estimated coefficients. ${ }^{18}$ We use a third variation to study the credit market and replace the index $i$ in equation (1) from a firm to a firm-bank pair. We collapsed the universe of bank names in annual reports into "state-owned" and "other" banks. This empirical strategy is similar to the one in Khwaja and Mian (2005). The main difference is that we exploit within firm-bank variation over time (i.e., before and after the plebiscite), and not only within firm variation. For this credit market analysis we use three dependent variables: (1) monetary value of debt in Chilean pesos, (2) an indicator for positive amounts of debt, and (3) the logarithm of debt.

\footnotetext{
${ }^{17}$ Any firm that is not part of a business group is assumed to be a business group on its own. There are 104 clusters in our dataset. We obtain similar results when we cluster using Newman (2004) community detection algorithm in our network of firms.

${ }^{18}$ For example, one might worry that firms in the energy sector anticipate increases in demand after the plebiscite and decide to increase their productive capacity accordingly. Including industry fixed effects after the plebiscite addresses this type of concern.
} 


\section{Results}

We present results in three parts. First, we estimate how firm inputs, profits, and the credit market changed during political transition. Second, we present empirical exercises to test for the role of links to the regime versus other variables. Third, we study the consequences of our findings in democracy. Overall, we find that (1) firms linked to the regime increased their productive capacity and enjoyed higher profits during political transition, (2) firms linked to the regime obtained more loans from state-owned banks during political transition, and (3) firms linked to the regime had better market outcomes in democracy. Section 5 tests for different explanations for these findings.

\subsection{Firms during political transition}

Columns 1 and 4 in Table 2-A show how investment, profits, productivity, and the number of workers changed after the plebiscite among firms with first direct links to the regime. Coefficients indicate that these firms increased their investment and enjoyed higher profits during political transition. In contrast, Table 2-B shows no significant changes in productivity or the number of workers. In terms of magnitudes, the standard deviations $(\sigma)$ in dictatorship imply that investment in physical capital increased by $0.40 \sigma$ and profits increased by $0.20 \sigma$, while changes in productivity and the number of workers are smaller than $0.05 \sigma$.

Columns 2 and 5 allow for firms with indirect links to respond differently than firms with no links. Coefficients for these firms indicate similar patterns during political transition but smaller in magnitude. Interestingly, the coefficient for firms with direct links increases, suggesting that accounting for indirect links is important. Columns 3 and 6 include industry fixed effects after the plebiscite and coefficients remain similar. The latter is our preferred specification because it compares firms within industries after $1988 .{ }^{19}$

Table 3 presents results for the credit market. Columns 1-3 present estimates using

\footnotetext{
${ }^{19}$ We present coefficients for the democracy period in Tables A.4 and A.5. However, we believe it is difficult to interpret them because firm responses during political transition could have easily persisted to the democratic period. We present coefficients for the democracy period simply for transparency. Results are similar if we only use the dictatorship and transition periods.
} 
debt in Chilean pesos as dependent variable. Firms with direct links increased their debt with state-owned banks during political transition. The coefficient is large, as can be seen from the average debt with these banks. Columns 4-6 show that the probability of having a positive amount of debt is also larger for these firms. Columns 7-9 show that debt over assets also increases significantly after the plebiscite. Remarkably, coefficients are always positive but smaller in magnitude for firms with indirect links ( $p$-values of $0.16,0.23$, and 0.07 , respectively). ${ }^{20}$ In addition to debt with banks, we also explored changes in stocks and bond issuances as other sources of funding and found no significant differences explained by links to the regime (Table A.6). Taken together, these results emphasize the importance of state-owned banks during political transition.

Even though equation (1) is a fairly non-parametric regression, the reader may worry about specification decisions affecting our results. Several checks suggest that previous results are not driven by this type of decisions. Indeed, results are similar when we use different parts of the empirical distribution to winsorize dependent variables (Table A.7), similar when we use a Solow residual to estimate productivity (Table A.8), similar when we collapse the data to three periods (dictatorship, transition, and democracy) to deal with potentially serially correlated outcomes (Bertrand et al., 2004, see column 1 in Table 4), and similar when we measure links to the regime in 1986 (instead of 1987, see Table A.9). The last specification check also confirms that credit market results are similar when we classify banks linked to the regime in three other ways: (1) banks that were privatized or received financial help during the 1982 economic crisis, (2) state-owned banks and large banks that were privatized by the regime, and (3) state-owned banks and banks with politically connected directors (Table A.10).

\subsection{The importance of links to the regime and the plebiscite}

As shown in Table 1, firms not only differ in their links to the Pinochet dictatorship, but also on other observable variables. We now present empirical exercises that suggest our findings are driven by links to Pinochet and not other variables. Because estimates account for firm and time fixed effects, we are concerned with time effects affecting firms

\footnotetext{
${ }^{20}$ The average firm had debt with five banks in the dictatorship period and this number did not change among firms with links after the plebiscite.
} 
differently. The following exercises allow for time effects of potential confounding variables, use matching approaches to estimate changes in firm behavior during political transition, and present placebo exercises that exploit the attempted murder of Pinochet in dictatorship and other elections in democracy. Tables 4 and 5 present the most relevant exercises. Additional results can be found in the Appendix.

Table 4 presents evidence for the importance of links and not other observable variables. Columns 2-5 add relevant controls to our preferred specification to study the influence of observables in our estimates. We measure controls before the plebiscite and allow their coefficients to change after the plebiscite. Reassuringly, results are similar when we control for an indicator for big firms - above the median of the firm size distribution an indicator for firms privatized by the dictatorship, an indicator for firms participating in a business group, and exporting firms. Column 6 includes all previously mentioned control variables and results are again similar. In addition, Table A.11 accounts for the effect of substituting links from the old to the new regime and results are again similar. ${ }^{21}$

We perform three additional exercises making use of differences in observables across firms. First, we flexibly control for the probability of having a link to the regime based on observables. We estimate two probit models to predict direct and indirect links using observable variables before the plebiscite - see Table A.12 - and include these "propensity scores" interacted with a linear trend as control variables. Column 7 present results and coefficients are similar. Second, we follow Crump et al. (2009) and restrict attention to firms with overlap in the propensity score distribution. Column 8 shows that the coefficients of interest are again similar. Third, we use the synthetic control approach proposed by Abadie and Gardeazabal (2003) and Abadie et al. (2010) and find similar results in terms of magnitude and statistical significance (Table A.13).

We also perform two placebo exercises to corroborate the importance of the plebiscite. The first exercise, presented in Table 5-A, restricts attention to the period 1985-1988 and examines outcomes before and after the third quarter of 1986, when a group of politically motivated individuals attempted to murder Pinochet, a well-known event at the time

\footnotetext{
${ }^{21}$ To measure links between firms and the new regime we used the methodology described in Appendix B but replaced the word "Pinochet" by the word "Concertacion." We identified seven firms that substituted links from the old to the new regime between 1988 and 1992.
} 
which can be interpreted as a failed end of the Pinochet regime. ${ }^{22}$ This exercise also serves as a test for the parallel trend assumption in our differences-in-differences framework. The second exercise, presented in Table 5-B, restricts attention to the period 1990-1997 and examines the time before and after the 1993 presidential election in columns 1-2. Due to data constraints, we repeat this exercise before and after the 1992 local elections for outcomes in columns 3-5. These elections serve as checks for the effect of elections which did not lead to a political transition. In both cases we observe smaller and not statistically significant point estimates. We interpret these additional results as further evidence for the importance of the plebiscite, an election which ended the Pinochet regime and initiated a political transition.

\section{An exploration of mechanisms}

This section provides an exploration of mechanisms that can potentially explain our findings. We first discuss a simple model of firms that can rationalize the majority of our results and then study alternative explanations. Although suggestive, we argue that the collection of findings in section 4 is most consistent with firms linked to the dictatorship making strategic investments to improve their market position after political transition. This conclusion is supported by auxiliary predictions derived from the model that we test empirically. In contrast, alternative explanations find little support.

\subsection{Strategic investments}

Our findings are theoretically consistent with entry deterrence models predicting increases in investment when there is a threat of competition (Dixit, 1980). In our context, the increase in competition comes from the potential increase in firm entry that democracy brings (Acemoglu, 2008). ${ }^{23}$ This model predicts that firms exploit their (now transitory) privileged relationship with state-owned banks during political transition to increase their productive capacity and deter entry in democracy. This model has the ability to

\footnotetext{
${ }^{22}$ More details about this event and the participants can be found in Peña (2007).

${ }^{23}$ Reassuringly, we observe an increase in firm entry after democratization in Chile. See Figure A.4.
} 
explain the increase in investment, higher profits, and increase in loans from state-owned banks during transition.

We present a formal theoretical model with the former predictions in appendix A. The model has three time periods (dictatorship, transition, and democracy) and three types of firms (direct links, indirect links, and no links). To solve the model we obtain best response functions for all firm-period pairs using an exogenous democratization announcement to study the transition period. Importantly, this model not only has the ability to predict the previously mentioned results, but also rationalizes the observed differences between firms with direct and indirect links. This model is also useful because we can use it to derive auxiliary predictions. We now discuss evidence for three additional predictions of the model.

In our model investing in physical capital is an effective way to reduce firm entry. If our findings are the consequence of strategic decisions, then we should expect higher investment during political transition in industries with higher entry costs. This is because of the higher marginal return to investment in these industries. To test for this, we follow Lambson and Jensen (1998) and construct a proxy for entry (sunk) costs by industry using data on property, plant, and equipment in the period 1985-87. We divide industries into those with more and less entry costs and use this variable to augment equation (1) with a triple difference. Table A.14 shows that investment among firms with links is indeed higher in more capital intensive industries during political transition, evidence which supports this first auxiliary prediction.

A second auxiliary prediction we can test is the relationship between the number of firms with links in an industry and firm entry in the same industry in democracy. To do this, we estimate industry-level regressions using the logarithm of number of firms as dependent variable and the share of firms with links as explanatory variable, controlling for industry fixed effects and time trends. We use this econometric strategy both in our data of listed firms and in a different dataset of firms we constructed using the Chilean annual manufacturing census, which also serves as an out-of-sample test. Table 6 provides some suggestive evidence that industries with more linked firms during political transition indeed had lower firm entry in democracy. Given the limited number of industries in our data, these results need to be interpreted with caution. 
A final prediction we can test is the following. If firms increasing their capacity during political transition obtained an advantage over firms that did not, we should expect the former to have higher profits in democracy. Indeed, we find that there is a positive and statistically significant relationship between capacity responses in transition and profits in democracy, and the effect is large when compared to investments in a different period. In particular, a one standard deviation increase in a firm's capacity response to the plebiscite is associated with an increase of 0.2 standard deviations in profits, which is larger than an increase of 0.1 standard deviations to investments in a different period. See Figure A.5 for details.

Although certainly suggestive, we believe that taken together these additional results provide some evidence for a strategic behavior of firms with links to the regime aiming to improve their market position in democracy. We now discuss alternative explanations.

\subsection{Alternative explanations}

In the remainder of this section we address the plausibility of alternative mechanisms. We first address the role of political and economic uncertainty, we then discuss the placement of individuals close to the regime in specific firms and, finally, we address the role of wealth transfers from the state to individuals in firms with links to the regime.

Are results driven by political and economic uncertainty? Several authors have shown that uncertainty affects investment and profits (e.g. Bloom 2009, Julio and Yook 2012) and it is sensible to think the period after the plebiscite is a time with uncertainty. Empirical evidence, however, suggest this is probably not relevant to understand our results. As our analysis includes time fixed effects, we are accounting for changes in macroeconomic variables that affect all firms. Hence, uncertainty can only explain our results if it affects firms with links differently after the plebiscite. Note, however, that Table 4 shows our results are similar when we interact variables with an indicator for the period after the plebiscite. Moreover, if firms with links are delaying investments because of uncertainty, we should observe an increase in their liquid assets before the plebiscite. But the difference in liquid assets between firms with and without links is not statistically different from zero before 1988. If anything, linked firms have less liquid assets. Therefore, the evidence suggests that results are not driven by uncertainty having heterogeneous effects on 
firms with and without links to the regime. The lack of economic and political uncertainty is unsurprising given the negotiations between the opposition coalition and the Pinochet regime, which made the transition to democracy peaceful and possible. ${ }^{24}$

Another explanation for our findings is that the Pinochet regime placed individuals as board members in firms that were expected to invest during political transition and perform well in democracy. Two pieces of evidence suggest that this "targeting of firms" is unlikely to be relevant in our context. Because our econometric strategy accounts for industry unobservable shocks after the plebiscite, our first piece of evidence against this interpretation comes from the difficulty of predicting future economic outcomes within industries. If the regime targeted firms, the regime should have been able to identify (1) firms that will behave in a precise way in the future, and (2) if and when there will be a political transition. Besides the observable variables for which we control for, it is hard to imagine what type of within industry information could the regime have had to target firms. In addition, the regime was planning on staying as the incumbent at least until 1996 (see section 2), making strategic targeting unlikely as a mechanism.

The second piece of evidence against this interpretation comes from the stock market. Recall that stock prices of firms with links to the regime decreased following the plebiscite. However, if these firms were expected to behave in a certain way during political transition, we should not observe a decrease in their stock value after the plebiscite. The reason behind this argument is that the plebiscite should not have revealed any new information if the regime expected the transition and the reaction of firms.

Another interpretation for our findings is that the Pinochet regime extracted wealth from state-owned banks and made transfers to firm owners before leaving power. This mechanism can explain the higher profits among firms with links during transition. Two pieces of evidence are, however, hard to reconcile with this interpretation. First, we observe higher profits among firms with links after the plebiscite, particularly among those with increases in productive capacity (Figure A.5). Because there is no a priori reason to expect wealth transfers should increase future profits, we think this interpretation cannot explain these results. Second, if the regime transferred resources to firm owners, we

\footnotetext{
${ }^{24}$ Ellman and Wantchekon (2000) provide a theoretical analysis of Chile's and other similar political transitions.
} 
should observe an increase in wealth extraction from firms by their owners, essentially the last step of the transfer process. This auxiliary prediction can be tested by studying changes in extraordinary dividends after the plebiscite, which we observe in annual reports. Table A.15 shows that owners of linked firms did not extract more wealth after 1988. In fact, if anything, we observe fewer extraordinary dividends among these firms.

\section{Conclusion}

To improve our understanding of the economic effects of democratizations, we studied the behavior of firms during political transition. Our empirical analysis focused on Chile's transition to democracy, which offered a unique opportunity to measure the network of firms with links to the dictatorship and important firm-level variables during political transition. Our analysis provided evidence consistent with firm distortions being transferred across political regimes as firms with links to the dictatorship seem to have successfully improved their market position using their political ties. We cannot, however, claim that this behavior was necessarily inefficient for the market. Although firms with links to the dictatorship were relatively unproductive and a source of misallocation, to compute the complete welfare implications we would need to fully characterize demand and supply in different industries, a task beyond the scope of this paper.

The reader might worry that Chile's transition to democracy differs from other transitions and our findings have limited external validity. Although certainly unique, we believe the timing of Chile's democratization provides a valuable starting point to evaluate the behavior of firms during political transition. If firms in a dictator's network have more accurate information about the future than other firms - the most likely case in our view - the kind of firm behavior we have documented could be magnified. Conversely, if the new regime is fragile and a reversal probable, firms may be less likely to respond during transition. In this sense, careful regulation of the credit and investment market during a democratization seems like a potentially effective policy to avoid persistence of distortions. One way to achieve this regulation is with government audits of investment projects, which have been shown to reduce corruption (Olken, 2007).

Besides the firm outcomes we have studied, there could be other economic and polit- 
ical areas affected in democracy. We believe the political arena is particularly important not only in the Chilean case, but potentially other settings as well. If the economic power that persists across regimes translates into political power in democracy, the old political regime could still exert influence and create political distortions. Recent corruption scandals in Chile suggests this is indeed the case as several firms have been accused of (illegally) financing electoral campaigns.

\section{References}

Abadie, A., Diamond, A., and Hainmueller, J. (2010). Synthetic control methods for comparative case studies: estimating the effect of California's tobacco control program. Journal of the American Statistical Association, 105(490):493-505.

Abadie, A. and Gardeazabal, J. (2003). The economic costs of conflict: a case study of the Basque country. American Economic Review, 93(1):113-132.

Acemoglu, D. (2008). Oligarchic versus democratic societies. Journal of the European Economic Association, 6(1):1-44.

Acemoglu, D., Hassan, T. A., and Tahoun, A. (2017a). The power of the street: evidence from Egypt's Arab Spring. Review of Financial Studies.

Acemoglu, D., Johnson, S., Kermani, A., Kwak, J., and Mitton, T. (2016). The value of connections in turbulent times: evidence from the United States. Journal of Financial Economics, 121(2):368-391.

Acemoglu, D., Naidu, S., Restrepo, P., and Robinson, J. (2017b). Democracy does cause growth. Journal of Political Economy.

Acemoglu, D. and Robinson, J. (2008). Persistence of power, elites, and institutions. American Economic Review, 98(1):267-293.

Acemoglu, D., Ticchi, D., and Vindigni, A. (2011). Emergence and persistence of inefficient states. Journal of the European Economic Association, 9(2):177-208.

Banerjee, A. V. and Duflo, E. (2014). Do firms want to borrow more? Testing credit constraints using a directed lending program. Review of Economic Studies, (81):572-607.

Barro, R. (1996). Democracy and growth. Journal of Economic Growth, 1(1):1-27.

Bertrand, M., Duflo, E., and Mullainathan, S. (2004). How much should we trust differences-in-differences estimates? Quarterly Journal of Economics, 119(1):249-275. 
Bertrand, M., Kramarz, F., Schoar, A., and Thesmar, D. (2007). Politicians, firms, and the political business cycle: evidence from France. Working Paper.

Blanes i Vidal, J., Draca, M., and Fons-Rosen, C. (2012). Revolving door lobbyists. American Economic Review, 102(7):3731-48.

Bloom, N. (2009). The impact of uncertainty shocks. Econometrica, 77(3):623-685.

Boas, T. C. (2015). Voting for democracy: campaign effects in chile's democratic transition. Latin American Politics and Society, 57(2):67-90.

Cauce (1988). Mito, temores y encuestas. Cauce Magazine.

Cavallo, A., Salazar, M., and Sepúlveda, O. (2011). La Historia Oculta del Régimen Militar: Memoria de una Época 1973-1988. Uqbar editores.

CEME (2004). Informe de la comisión investigadora encargada de analizar presuntas irregularidades en las privatizaciones de empresas del estado ocurridas con anterioridad al año 1990. Centro de Estudios Miguel Enriquez.

Cingano, F. and Pinotti, P. (2013). Politicians at work: the private returns and social costs of political connections. Journal of the European Economic Association, 11(2):433-465.

Claessens, S., Feijen, E., and Laeven, L. (2008). Political connections and preferential access to finance: the role of campaign contributions. Journal of Financial Economics, 88:554-580.

Colonnelli, E. and Prem, M. (2017). Corruption and firms. Working Paper.

Crump, R. K., Hotz, V. J., Imbens, G. W., and Mitnik, O. A. (2009). Dealing with limited overlap in estimation of average treatment effects. Biometrika, 96(1):187-199.

Dixit, A. (1980). The role of investment in entry deterrence. Economic Journal, 90(357):95106.

Doucouliagos, H. and Ulubasoglu, M. (2008). Democracy and economic growth: a metaanalysis. American Journal of Political Science, 52(1):61-83.

Ellman, M. and Wantchekon, L. (2000). Electoral competition under the threat of political unrest. Quarterly Journal of Economics, 115(2):499-531.

Engel, E. and Venetoulias, A. (1992). The chilean plebiscite: projections without historic data. Journal of the American Statistical Association, 87(420):933-941.

Faccio, M. (2006). Politically connected firms. American Economic Review, 96(1):369-386.

Faccio, M., Masulis, R. W., and McConnell, J. J. (2006). Political connections and corporate bailouts. Journal of Finance, LXI(6):2597-2635.

Ferguson, T. and Voth, H.-J. (2008). Betting on Hitler: The value of political connections in nazy Germany. Quarterly Journal of Economics, 123(1):101-137. 
Fisman, R. (2001). Estimating the value of political connections. American Economic Review, 91(4):1095-1102.

Fracassi, C. (2016). Corporate finance policies and social networks. Management Science, pages 1-19.

Girardi, D. and Bowles, S. (2017). Institutional shocks and economic outcomes: Allende's election, Pinochet's cup and the santiago stock market. Working Paper.

González, F. and Prem, M. (2017). Can television bring down a dictator? Evidence from Chile's 'No' campaign. Working Paper.

Hirmas, M. E. (1993). The chilean case: Television in the 1988 plebiscite. In Skidmore, T. E., editor, Television, Politics, and the Transition to Democracy in Latin America. The Johns Hopkins University Press: Baltimore and London.

Hsieh, C.-T. and Klenow, P. J. (2009). Misallocation and manufacturing TFP in China and India. Quarterly Journal of Economics, 124(4):1403-1448.

Huneeus, C. (2000). Technocrats and politicians in an authoritarian regime. The 'ODEPLAN boys' and the 'Gremialists' in Pinochet's Chile. Journal of Latin American Studies, 32:461-501.

Huneeus, C. (2006). The Pinochet Regime. Lynne Rienner Publishers.

Jackson, M. O. and Rogers, B. W. (2005). The economics of small worlds. Journal of the European Economic Association, 3(2-3):617-627.

Jayachandran, S. (2006). The Jeffords effects. Journal of Law and Economics, XLIX:397-425.

Julio, B. and Yook, Y. (2012). Political uncertainty and corporate investment cycles. Journal of Finance, LXVII(1):45-83.

Khwaja, A. I. and Mian, A. (2005). Do lenders favor politically connected firms? Rent provision in an emerging financial market. Quarterly Journal of Economics, 120(4):13711411.

Khwaja, A. I., Mian, A., and Qamar, A. (2011). Bank credit and business networks. Working Paper.

Lambson, V. E. and Jensen, F. E. (1998). Sunk costs and firm value variability: theory and evidence. American Economic Review, 88(1):307-313.

Leon-Dermota, K. (2003). ...And Well Tied Down: Chile's Press Under Democracy. Praeger.

Martínez Bravo, M. (2014). The role of local officials in new democracies: evidence from Indonesia. American Economic Review, 104(4):1244-87.

Martínez Bravo, M., Mukherjee, P., and Stegmann, A. (2018). The non-democratic roots of elite capture: evidence from Soeharto mayors in Indonesia. Econometrica, forthcoming. 
Méndez, R., Godoy, O., Barros, E., and Fontaine, A. (1988). ¿Por qué ganó el no? Centro de Estudios Públicos.

Mönckeberg, M. O. (2015). El Saqueo de los Grupos Económicos al Estado Chileno. De Bolsillo.

Murtin, F. and Wacziarg, R. (2014). The democratic transition. Journal of Economic Growth, 19:141-181.

Newman, M. E. (2004). Fast algorithm for detecting community structure in networks. Physical review E, 69(6):066133.

Olken, B. A. (2007). Monitoring corruption: evidence from a field experiment in Indonesia. Journal of Political Economy, 115(2):200-249.

Olley, G. S. and Pakes, A. (1996). The dynamics of productivity in the telecommunications equipment industry. Econometrica, 64:1263-1297.

Ossandón, J. and Tironi, E., editors (2013). Adaptación: La Empresa Chilena Después de Friedman. Ediciones Universidad Diego Portales.

Papaioannou, E. and Siourounis, G. (2008a). Democratisation and growth. Economic Journal, 118:1520-1551.

Papaioannou, E. and Siourounis, G. (2008b). Economic and social factors driving the third wave of democratization. Journal of Comparative Economics, 36:365-387.

Patnam, M. (2013). Corporate networks and peer effects in firm policies. Working Paper.

Peña, J. C. (2007). Los fusileros. De Bolsillo.

Persson, T. and Tabellini, G. (2006). Democracy and development: the devil in the details. American Economic Review, 96(2):319-324.

Rodrik, D. and Wacziarg, R. (2005). Do democratic transitions produce bad economic outcomes? American Economic Review, 95(2):50-55.

Roland, G. (2002). The political economy of transition. Journal of Economic Perspectives, 16(1):29-50.

Silva, E. (1996). From dictatorship to democracy: the business-state nexus in Chile's economic transformation, 1975-1994. Comparative Politics, 28(3):299-320.

Silva, P. (1991). Technocrats and politics in Chile: from the Chicago boys to the CIEPLAN monks. Journal of Latin American Studies, 23:385-410.

Tavares, J. and Wacziarg, R. (2001). How democracy affects growth. European Economic Review, 45(8):1341-1378.

United Nations (2008). International standard industrial classification of all economic activities. Statistical Papers Series M No.4/Rev.4, Department of Economic and Social Affairs. 


\section{Figure 1: Network of firms}

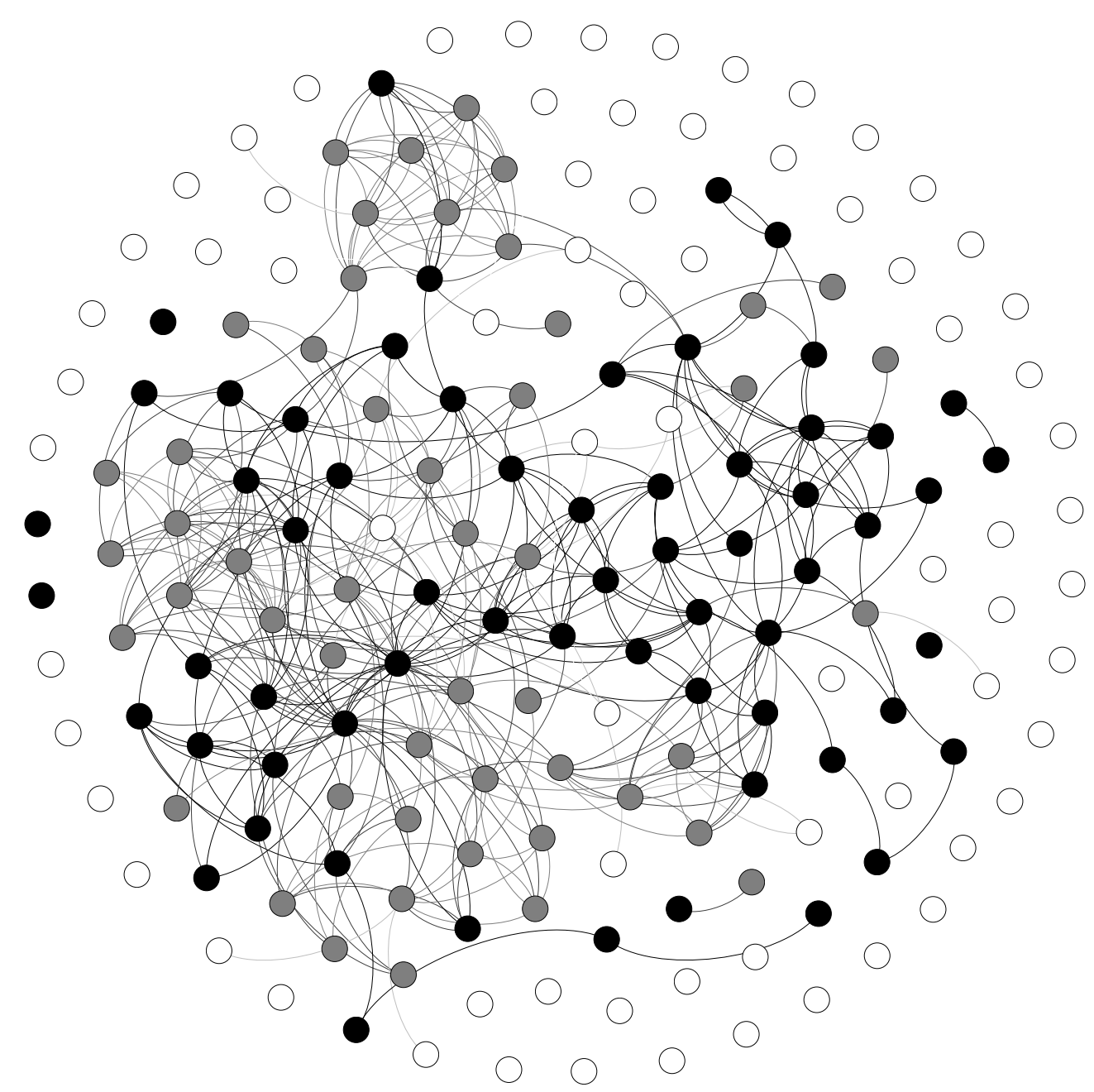

Notes: Network of firms listed in the Chilean stock market in 1987. Each circle represents a firm. We define a link "—" between firms using board linkages. Firms denoted by "•" had a direct link to the Pinochet regime (first degree link), firms denoted by "๑" had no links to the regime but had a link to firms with a link (second degree link), and firms denoted by "○" did not have links to the regime nor linked firms. The average firm is linked to 4.7 other firms by board linkages. The average number of links between any two firms that can be connected is 3.3, the maximum distance between any two firms is 9 , the global clustering coefficient is 0.48 , and the fraction of firms in the giant network is 0.44 . This network of firms shows some features of "small world," low diameter, and high clustering discussed by Jackson and Rogers (2005). The network is our own construction based on data provided by Chile's stock market regulatory agency. 
Figure 2: The stock market

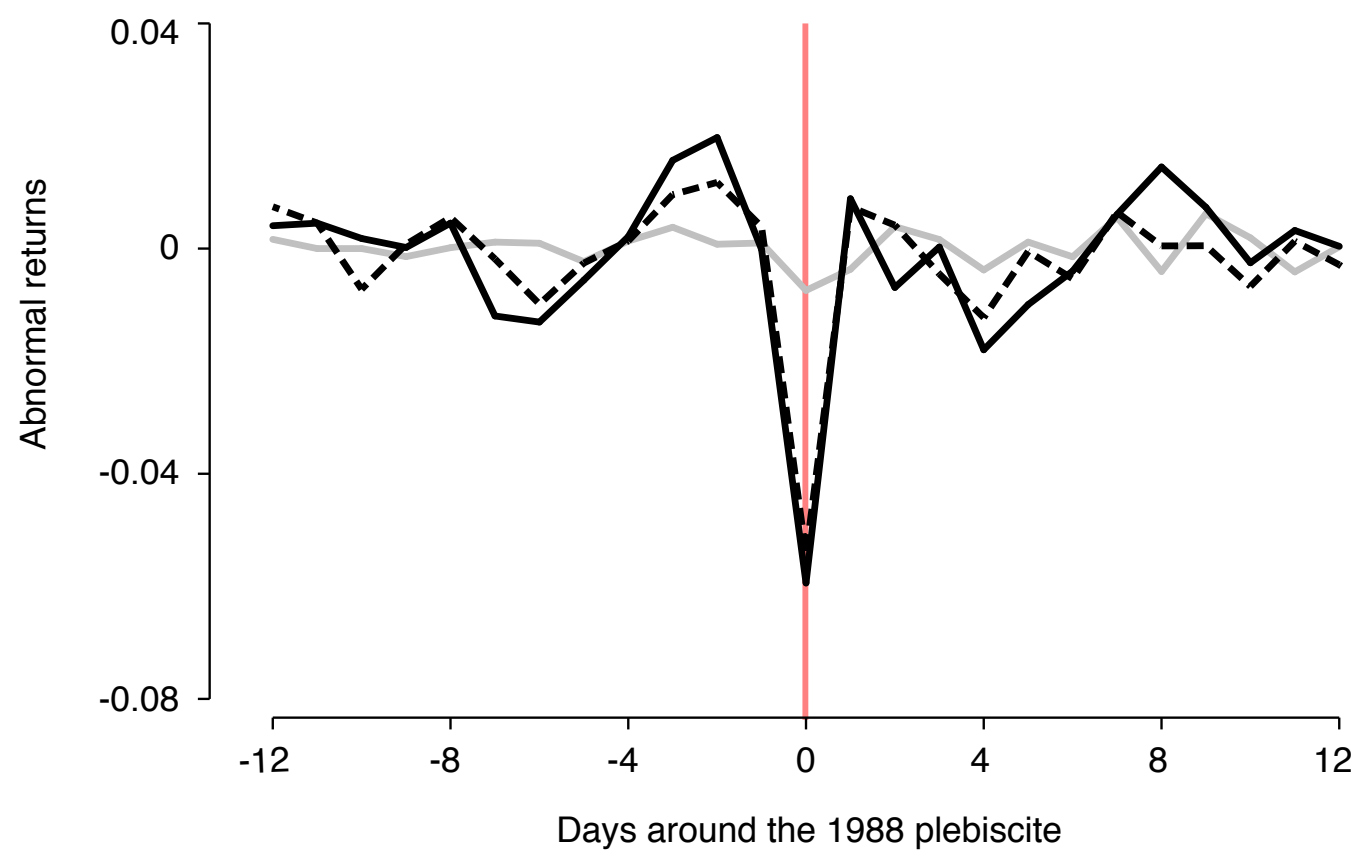

Direct link to the Pinochet regime

-.-... Indirect link

No link

Notes: Own construction based on stock prices collected from contemporary newspaper "El Mercurio," accessed through Chile's National Library. The vertical red line denotes the date of the plebiscite (October 5, 1988). 
Figure 3: Time series for firm-level outcomes
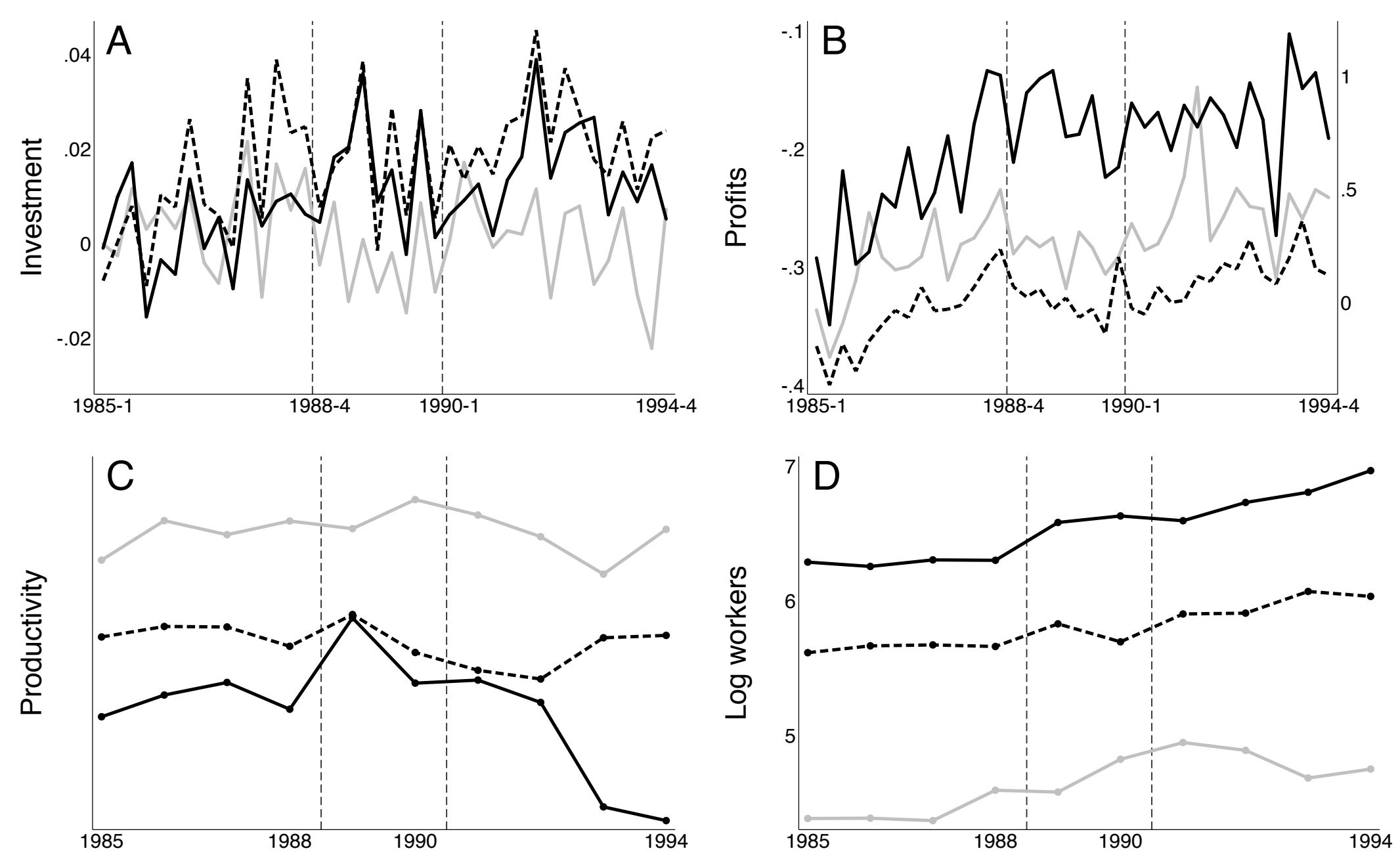

Notes: Average investment in physical capital in Panel A; profits before interests, taxes and depreciation (standardized) in Panel B; productivity using Olley and Pakes (1996) procedure in Panel C (no meaningful absolute value, so numbers in the $y$-axis are omitted); and the logarithm of workers in Panel D. Legend for different groups of firms: direct connections (solid black), indirect connections (dash black), and no connections (gray). The events under study are the plebiscite (1988-4) and the beginning of the democratic period in Chile (1990-1). Panels A and B use quarterly variation. Panels C and D use annual variation. 


\section{Table 1: Firms during the Pinochet dictatorship}

\begin{tabular}{|c|c|c|c|c|c|c|}
\hline \multirow[b]{2}{*}{ A-Quarterly dataset } & \multirow{2}{*}{$\begin{array}{c}\begin{array}{c}\text { Firms } \\
\text { without } \\
\text { links }\end{array} \\
(1)\end{array}$} & \multirow{2}{*}{$\begin{array}{l}\text { Firms with } \\
\text { direct links } \\
\text { to Pinochet } \\
\text { (2) }\end{array}$} & \multirow{2}{*}{$\begin{array}{c}\text { Firms with } \\
\text { indirect links } \\
\text { to Pinochet }\end{array}$} & \multicolumn{3}{|c|}{ Uni-variate regression } \\
\hline & & & & $(2)-(1)$ & $(3)-(1)$ & $(2)-(3)$ \\
\hline Investment & $\begin{array}{c}0.00 \\
(0.05)\end{array}$ & $\begin{array}{l}-0.00 \\
(0.05)\end{array}$ & $\begin{array}{c}0.01 \\
(0.06)\end{array}$ & $\begin{array}{l}-0.00 \\
(0.01)\end{array}$ & $\begin{array}{c}0.00 \\
(0.01)\end{array}$ & $\begin{array}{l}-0.01 \\
(0.01)\end{array}$ \\
\hline Profits & $\begin{array}{l}-0.32 \\
(0.24)\end{array}$ & $\begin{array}{c}0.39 \\
(1.48)\end{array}$ & $\begin{array}{l}-0.11 \\
(0.52)\end{array}$ & $\begin{array}{l}0.70^{* * *} \\
(0.17)\end{array}$ & $\begin{array}{l}0.20^{* *} \\
(0.08)\end{array}$ & $\begin{array}{l}0.50^{* *} \\
(0.20)\end{array}$ \\
\hline Log assets & $\begin{array}{l}14.52 \\
(2.10)\end{array}$ & $\begin{array}{l}17.55 \\
(1.87)\end{array}$ & $\begin{array}{l}16.82 \\
(1.37)\end{array}$ & $\begin{array}{c}2.99^{* * *} \\
(0.43)\end{array}$ & $\begin{array}{c}2.27^{* * *} \\
(0.41)\end{array}$ & $\begin{array}{l}0.72^{*} \\
(0.37)\end{array}$ \\
\hline \multicolumn{7}{|l|}{ B-Annual dataset } \\
\hline Log workers & $\begin{array}{c}4.38 \\
(1.99)\end{array}$ & $\begin{array}{c}6.27 \\
(1.65)\end{array}$ & $\begin{array}{c}5.65 \\
(1.39)\end{array}$ & $\begin{array}{l}1.90^{* * *} \\
(0.29)\end{array}$ & $\begin{array}{c}1.27^{* * *} \\
(0.29)\end{array}$ & $\begin{array}{c}0.63^{* * *} \\
(0.24)\end{array}$ \\
\hline Productivity & $\begin{array}{l}-0.47 \\
(1.69)\end{array}$ & $\begin{array}{l}-1.52 \\
(1.92)\end{array}$ & $\begin{array}{l}-1.08 \\
(1.54)\end{array}$ & $\begin{array}{c}-1.05^{* * *} \\
(0.29)\end{array}$ & $\begin{array}{c}-0.61^{* *} \\
(0.27)\end{array}$ & $\begin{array}{l}-0.45 \\
(0.27)\end{array}$ \\
\hline Capital misallocation & $\begin{array}{l}-0.31 \\
(1.11)\end{array}$ & $\begin{array}{l}-0.71 \\
(0.53)\end{array}$ & $\begin{array}{l}-0.70 \\
(0.70)\end{array}$ & $\begin{array}{l}-0.43^{*} \\
(0.23)\end{array}$ & $\begin{array}{l}-0.41 \\
(0.26)\end{array}$ & $\begin{array}{l}-0.03 \\
(0.17)\end{array}$ \\
\hline Output misallocation & $\begin{array}{c}0.88 \\
(0.14)\end{array}$ & $\begin{array}{c}0.76 \\
(0.81)\end{array}$ & $\begin{array}{c}0.87 \\
(0.49)\end{array}$ & $\begin{array}{l}-0.10 \\
(0.14)\end{array}$ & $\begin{array}{l}-0.02 \\
(0.11)\end{array}$ & $\begin{array}{l}-0.07 \\
(0.17)\end{array}$ \\
\hline Debt with state-owned banks & $\begin{array}{c}3.7 \\
(17.2)\end{array}$ & $\begin{array}{c}17.0 \\
(48.0)\end{array}$ & $\begin{array}{c}20.6 \\
(45.9)\end{array}$ & $\begin{array}{c}13.4^{* * *} \\
(4.9)\end{array}$ & $\begin{array}{c}17.0^{* * *} \\
(4.8)\end{array}$ & $\begin{array}{l}3.6 \\
(6.6)\end{array}$ \\
\hline Debt with other banks & $\begin{array}{c}17.8 \\
(46.4)\end{array}$ & $\begin{array}{c}87.8 \\
(117.7)\end{array}$ & $\begin{array}{c}63.0 \\
(92.0)\end{array}$ & $\begin{array}{c}70.0^{* * *} \\
(12.1)\end{array}$ & $\begin{array}{c}45.2^{* * *} \\
(10.1)\end{array}$ & $\begin{array}{l}24.8^{*} \\
(15.0)\end{array}$ \\
\hline \multicolumn{7}{|l|}{ C-Time invariant } \\
\hline Age in 1987 & $\begin{array}{c}39 \\
(27)\end{array}$ & $\begin{array}{c}53 \\
(30)\end{array}$ & $\begin{array}{c}49 \\
(29)\end{array}$ & $\begin{array}{l}14^{* *} \\
(6)\end{array}$ & $\begin{array}{l}10 \\
(7)\end{array}$ & $\begin{array}{c}4 \\
(7)\end{array}$ \\
\hline Exporter & $\begin{array}{c}0.26 \\
(0.43)\end{array}$ & $\begin{array}{c}0.48 \\
(0.50)\end{array}$ & $\begin{array}{c}0.57 \\
(0.50)\end{array}$ & $\begin{array}{l}0.27^{* *} \\
(0.10)\end{array}$ & $\begin{array}{c}0.34^{* * *} \\
(0.11)\end{array}$ & $\begin{array}{l}-0.07^{*} \\
(0.11)\end{array}$ \\
\hline Privatized by Pinochet & $\begin{array}{c}0.11 \\
(0.31)\end{array}$ & $\begin{array}{c}0.56 \\
(0.50)\end{array}$ & $\begin{array}{c}0.33 \\
(0.47)\end{array}$ & $\begin{array}{c}0.44^{* * *} \\
(0.09)\end{array}$ & $\begin{array}{l}0.21^{* *} \\
(0.10)\end{array}$ & $\begin{array}{l}0.22^{*} \\
(0.11)\end{array}$ \\
\hline Part of a business group & $\begin{array}{c}0.02 \\
(0.15)\end{array}$ & $\begin{array}{c}0.21 \\
(0.41)\end{array}$ & $\begin{array}{c}0.39 \\
(0.49)\end{array}$ & $\begin{array}{c}0.19^{* * *} \\
(0.07)\end{array}$ & $\begin{array}{c}0.37^{* * *} \\
(0.09)\end{array}$ & $\begin{array}{l}-0.18^{*} \\
(0.11)\end{array}$ \\
\hline
\end{tabular}

Notes: Average of main variables in the period 1985-1987. Data for 118 firms in Panel A, 99 firms in the first four rows of Panel B, 113 firms in the last two of rows of Panel B. Debt is measured in billions of Chilean pesos. Standard deviation in parentheses in columns $1-3$, and standard error in parentheses in the last three columns. Significance level: ${ }^{* * *}$ $p<0.01,{ }^{* *} p<0.05,{ }^{*} p<0.1$. More details in section 3.1. 
Table 2: Firms during Chile's transition to democracy

\begin{tabular}{|c|c|c|c|c|c|c|}
\hline \multirow[b]{2}{*}{ Panel A } & (1) & (2) & (3) & (4) & (5) & (6) \\
\hline & \multicolumn{3}{|c|}{ Investment } & \multicolumn{3}{|c|}{ Profits } \\
\hline Direct link $\times$ Transition & $\begin{array}{c}0.012 \\
(0.007)\end{array}$ & $\begin{array}{l}0.018^{* *} \\
(0.007)\end{array}$ & $\begin{array}{l}0.018^{* *} \\
(0.008)\end{array}$ & $\begin{array}{c}0.308^{* * *} \\
(0.099)\end{array}$ & $\begin{array}{c}0.350^{* * *} \\
(0.099)\end{array}$ & $\begin{array}{c}0.290^{* * *} \\
(0.100)\end{array}$ \\
\hline Indirect link $\times$ Transition & & $\begin{array}{c}0.013 \\
(0.008)\end{array}$ & $\begin{array}{c}0.014 \\
(0.009)\end{array}$ & & $\begin{array}{l}0.096^{* *} \\
(0.044)\end{array}$ & $\begin{array}{l}0.115^{*} \\
(0.069)\end{array}$ \\
\hline $\begin{array}{l}\text { Firms } \\
\text { Observations } \\
\text { Firm and time F.E. } \\
\text { Industry F.E. } \times \text { Post }\end{array}$ & $\begin{array}{c}118 \\
4,694 \\
x\end{array}$ & $\begin{array}{c}118 \\
4,694 \\
x\end{array}$ & $\begin{array}{l}118 \\
4,694 \\
x \\
x\end{array}$ & $\begin{array}{c}118 \\
4,692 \\
x\end{array}$ & $\begin{array}{c}118 \\
4,692 \\
x\end{array}$ & $\begin{array}{l}118 \\
4,692 \\
x \\
x\end{array}$ \\
\hline Panel B & & roductivit & & & Log worker & \\
\hline Direct link $\times$ Transition & $\begin{array}{c}0.046 \\
(0.158)\end{array}$ & $\begin{array}{l}-0.068 \\
(0.174)\end{array}$ & $\begin{array}{l}-0.065 \\
(0.177)\end{array}$ & $\begin{array}{c}0.022 \\
(0.106)\end{array}$ & $\begin{array}{c}0.020 \\
(0.106)\end{array}$ & $\begin{array}{c}0.028 \\
(0.108)\end{array}$ \\
\hline Indirect link $\times$ Transition & & $\begin{array}{l}-0.224^{*} \\
(0.119)\end{array}$ & $\begin{array}{l}-0.230^{*} \\
(0.118)\end{array}$ & & $\begin{array}{l}-0.006 \\
(0.089)\end{array}$ & $\begin{array}{l}-0.004 \\
(0.089)\end{array}$ \\
\hline Firms & 99 & 99 & 99 & 99 & 99 & 99 \\
\hline Observations & 792 & 792 & 792 & 792 & 792 & 792 \\
\hline $\begin{array}{l}\text { Firm and time F.E. } \\
\text { Industry F.E. } \times \text { Post }\end{array}$ & $\mathrm{x}$ & $\mathrm{x}$ & $\begin{array}{l}\mathrm{x} \\
\mathrm{x}\end{array}$ & $x$ & $x$ & $\begin{array}{l}\mathrm{x} \\
\mathrm{x}\end{array}$ \\
\hline
\end{tabular}

Notes: Panel A uses a quarterly data and Panel B uses annual data. Both panels use data for the period 1985-1994. The "Transition" period corresponds to the time between the plebiscite (October 1988) and the arrival of the new democratic government (March 1990). Robust standard errors are clustered at the business group level and are reported in parentheses. There are 104 clusters in Panel A and 88 clusters in Panel B. Significance level: ${ }^{* * *} p<0.01,{ }^{* *} p<0.05,{ }^{*} p<0.1$. More details in section 4 . 
Table 3: The credit market during political transition

Dependent variable (Debt) is total debt with banks, measured from annual reports

\begin{tabular}{|c|c|c|c|c|c|c|c|c|c|}
\hline & \multicolumn{3}{|c|}{ Debt } & \multicolumn{3}{|c|}{$\begin{array}{l}\text { Indicator for } \\
\text { positive debt }\end{array}$} & \multicolumn{3}{|c|}{$\begin{array}{c}\text { Debt } \\
\text { over assets }\end{array}$} \\
\hline & $(1)$ & $(2)$ & (3) & (4) & (5) & (6) & $(7)$ & (8) & $(9)$ \\
\hline Direct link $\times$ Transition $\times$ State bank & $\begin{array}{c}16.7 \\
(12.9)\end{array}$ & $\begin{array}{c}29.8^{* * *} \\
(10.2)\end{array}$ & $\begin{array}{c}29.8^{* * *} \\
(10.2)\end{array}$ & $\begin{array}{l}0.16^{* *} \\
(0.07)\end{array}$ & $\begin{array}{l}0.20^{* *} \\
(0.08)\end{array}$ & $\begin{array}{l}0.20^{* *} \\
(0.08)\end{array}$ & $\begin{array}{l}0.06^{* *} \\
(0.03)\end{array}$ & $\begin{array}{l}0.08^{* *} \\
(0.03)\end{array}$ & $\begin{array}{l}0.08^{* *} \\
(0.03)\end{array}$ \\
\hline Indirect link $\times$ Transition $\times$ State bank & & $\begin{array}{l}28.3 \\
(20.0)\end{array}$ & $\begin{array}{c}28.4 \\
(20.1)\end{array}$ & & $\begin{array}{c}0.09 \\
(0.07)\end{array}$ & $\begin{array}{c}0.09 \\
(0.07)\end{array}$ & & $\begin{array}{c}0.05 \\
(0.04)\end{array}$ & $\begin{array}{c}0.05 \\
(0.04)\end{array}$ \\
\hline Mean of dependent variable & 29.2 & 29.2 & 29.2 & 0.38 & 0.38 & 0.38 & 0.06 & 0.06 & 0.06 \\
\hline Firms & 113 & 113 & 113 & 113 & 113 & 113 & 113 & 113 & 113 \\
\hline Observations & 2,073 & 2,073 & 2,073 & 2,073 & 2,073 & 2,073 & 2,073 & 2,073 & 2,073 \\
\hline Double interactions & $\mathrm{x}$ & $\mathrm{x}$ & $\mathrm{x}$ & $\mathrm{x}$ & $\mathrm{x}$ & $\mathrm{x}$ & $\mathrm{x}$ & $\mathrm{x}$ & $\mathrm{x}$ \\
\hline Firm-bank F.E. & $x$ & $x$ & $x$ & $x$ & $x$ & $x$ & $x$ & $x$ & $x$ \\
\hline Year F.E. & $x$ & $x$ & $x$ & $x$ & $x$ & $x$ & $x$ & $x$ & $x$ \\
\hline Industry F.E. $\times$ Post & $x$ & $x$ & $x$ & $x$ & $x$ & $x$ & $x$ & $x$ & $x$ \\
\hline
\end{tabular}

Notes: These regressions use the annual dataset of firms in the period 1985-1994. The unit of observation is a firm-bank relationship per year. Double interactions include "period and bank" interaction terms, and "link type and period" interaction terms. Robust standard errors are clustered at the business group level and are reported in parentheses. The number of clusters is 99. Significance level: ${ }^{* * *} p<0.01,{ }^{* *} p<0.05,{ }^{*} p<0.1$. More details in section 4. 


\section{Table 4: The importance of links to the regime}

\begin{tabular}{|c|c|c|c|c|c|c|c|c|}
\hline \multirow[b]{3}{*}{ Investment } & \multirow[b]{2}{*}{ Pre/Post } & \multicolumn{5}{|c|}{ Control variables } & \multirow[b]{2}{*}{ Pscore } & \multirow[b]{2}{*}{ Matching } \\
\hline & & Big firms & Privatized & Bus. Group & Exporter & All & & \\
\hline & $(1)$ & $(2)$ & (3) & $(4)$ & (5) & (6) & (7) & (8) \\
\hline Direct link $\times$ Transition & $\begin{array}{l}0.019^{* *} \\
(0.008)\end{array}$ & $\begin{array}{l}0.019^{* *} \\
(0.009)\end{array}$ & $\begin{array}{l}0.017^{* *} \\
(0.008)\end{array}$ & $\begin{array}{l}0.018^{* *} \\
(0.009)\end{array}$ & $\begin{array}{l}0.018^{* *} \\
(0.008)\end{array}$ & $\begin{array}{l}0.018^{*} \\
(0.009)\end{array}$ & $\begin{array}{l}0.017^{*} \\
(0.009)\end{array}$ & $\begin{array}{l}0.019^{* *} \\
(0.009)\end{array}$ \\
\hline Indirect link $\times$ Transition & $\begin{array}{l}0.015^{*} \\
(0.009)\end{array}$ & $\begin{array}{c}0.015 \\
(0.009)\end{array}$ & $\begin{array}{c}0.014 \\
(0.009)\end{array}$ & $\begin{array}{c}0.014 \\
(0.009)\end{array}$ & $\begin{array}{c}0.014 \\
(0.009)\end{array}$ & $\begin{array}{c}0.013 \\
(0.010)\end{array}$ & $\begin{array}{c}0.013 \\
(0.009)\end{array}$ & $\begin{array}{c}0.015 \\
(0.010)\end{array}$ \\
\hline \multicolumn{9}{|l|}{ Profits } \\
\hline Direct link $\times$ Transition & $\begin{array}{c}0.297^{* * *} \\
(0.101)\end{array}$ & $\begin{array}{l}0.218^{* *} \\
(0.100)\end{array}$ & $\begin{array}{l}0.228^{* *} \\
(0.113)\end{array}$ & $\begin{array}{c}0.341^{* * *} \\
(0.105)\end{array}$ & $\begin{array}{c}0.282^{* * *} \\
(0.101)\end{array}$ & $\begin{array}{l}0.218^{* *} \\
(0.108)\end{array}$ & $\begin{array}{l}0.252^{* *} \\
(0.100)\end{array}$ & $\begin{array}{c}0.136 \\
(0.120)\end{array}$ \\
\hline Indirect link $\times$ Transition & $\begin{array}{c}0.106 \\
(0.064)\end{array}$ & $\begin{array}{c}0.062 \\
(0.078)\end{array}$ & $\begin{array}{c}0.095 \\
(0.080)\end{array}$ & $\begin{array}{l}0.194^{*} \\
(0.110)\end{array}$ & $\begin{array}{c}0.107 \\
(0.080)\end{array}$ & $\begin{array}{l}0.109^{*} \\
(0.106)\end{array}$ & $\begin{array}{c}0.082 \\
(0.083)\end{array}$ & $\begin{array}{c}0.070 \\
(0.072)\end{array}$ \\
\hline \multicolumn{9}{|l|}{ Productivity } \\
\hline Direct link $\times$ Transition & $\begin{array}{c}-0.014 \\
(0.143)\end{array}$ & $\begin{array}{l}-0.178 \\
(0.158)\end{array}$ & $\begin{array}{l}-0.177 \\
(0.158)\end{array}$ & $\begin{array}{l}-0.064 \\
(0.179)\end{array}$ & $\begin{array}{l}-0.076 \\
(0.177)\end{array}$ & $\begin{array}{c}-0.092 \\
(0.128)\end{array}$ & $\begin{array}{l}-0.084 \\
(0.146)\end{array}$ & $\begin{array}{l}-0.053 \\
(0.147)\end{array}$ \\
\hline Indirect link $\times$ Transition & $\begin{array}{l}-0.156^{*} \\
(0.086)\end{array}$ & $\begin{array}{c}-0.277^{* *} \\
(0.126)\end{array}$ & $\begin{array}{c}-0.277^{* *} \\
(0.128)\end{array}$ & $\begin{array}{l}-0.230^{*} \\
(0.118)\end{array}$ & $\begin{array}{c}-0.239^{* *} \\
(0.117)\end{array}$ & $\begin{array}{c}-0.189^{* *} \\
(0.082)\end{array}$ & $\begin{array}{l}-0.202 \\
(0.131)\end{array}$ & $\begin{array}{l}-0.265^{*} \\
(0.149)\end{array}$ \\
\hline \multicolumn{9}{|l|}{ Log workers } \\
\hline Direct link $\times$ Transition & $\begin{array}{l}0.167^{*} \\
(0.089)\end{array}$ & $\begin{array}{c}0.041 \\
(0.115)\end{array}$ & $\begin{array}{c}0.041 \\
(0.115)\end{array}$ & $\begin{array}{c}0.028 \\
(0.108)\end{array}$ & $\begin{array}{c}0.027 \\
(0.108)\end{array}$ & $\begin{array}{l}0.194^{*} \\
(0.103)\end{array}$ & $\begin{array}{c}0.049 \\
(0.115)\end{array}$ & $\begin{array}{l}-0.038 \\
(0.155)\end{array}$ \\
\hline Indirect link $\times$ Transition & $\begin{array}{c}0.103 \\
(0.077)\end{array}$ & $\begin{array}{c}0.011 \\
(0.096)\end{array}$ & $\begin{array}{c}0.011 \\
(0.096)\end{array}$ & $\begin{array}{l}-0.004 \\
(0.089)\end{array}$ & $\begin{array}{l}-0.005 \\
(0.090)\end{array}$ & $\begin{array}{l}0.163^{* *} \\
(0.081)\end{array}$ & $\begin{array}{c}0.017 \\
(0.102)\end{array}$ & $\begin{array}{c}0.088 \\
(0.121)\end{array}$ \\
\hline \multicolumn{9}{|l|}{ Credit market } \\
\hline Direct link $\times$ Transition $\times$ State bank & $\begin{array}{l}26.8^{* *} \\
(11.4)\end{array}$ & $\begin{array}{l}25.4^{* *} \\
(11.6)\end{array}$ & $\begin{array}{c}17.5 \\
(12.4)\end{array}$ & $\begin{array}{c}36.2^{* * *} \\
(11.0)\end{array}$ & $\begin{array}{l}27.2^{* *} \\
(10.6)\end{array}$ & $\begin{array}{l}22.0^{*} \\
(12.2)\end{array}$ & $\begin{array}{c}30.7^{* * *} \\
(10.9)\end{array}$ & $\begin{array}{c}18.1 \\
(11.4)\end{array}$ \\
\hline Indirect link $\times$ Transition $\times$ State bank & $\begin{array}{c}30.0 \\
(19.8)\end{array}$ & $\begin{array}{c}24.6 \\
(18.7)\end{array}$ & $\begin{array}{c}22.7 \\
(17.6)\end{array}$ & $\begin{array}{c}40.5 \\
(25.1)\end{array}$ & $\begin{array}{c}24.1 \\
(18.1)\end{array}$ & $\begin{array}{c}31.4 \\
(20.6)\end{array}$ & $\begin{array}{c}29.2 \\
(20.0)\end{array}$ & $\begin{array}{c}15.9 \\
(14.8)\end{array}$ \\
\hline Firm and time F.E. & $\mathrm{x}$ & $\mathrm{x}$ & $x$ & $x$ & $\mathrm{x}$ & $x$ & $x$ & $\mathrm{x}$ \\
\hline Industry F.E. $\times$ Post & $\mathrm{x}$ & $\mathrm{x}$ & $\mathrm{x}$ & $\mathrm{x}$ & $\mathrm{x}$ & $\mathrm{x}$ & $\mathrm{x}$ & $\mathrm{x}$ \\
\hline
\end{tabular}

Notes: These regressions use the annual or quarterly datasets of firms in the period 19851994. The number of firms, observations, and clusters are presented in Tables 2 and 3. Robust standard errors are clustered at the business group level and are reported in parentheses. Significance level: ${ }^{* *} p<0.01,{ }^{* *} p<0.05,{ }^{*} p<0.1$. More details in section 4. 
Table 5: The importance of the plebiscite

\begin{tabular}{|c|c|c|c|c|c|}
\hline & $\frac{\text { Investment }}{(1)}$ & $\frac{\text { Profits }}{(2)}$ & $\frac{\text { Productivity }}{(3)}$ & $\frac{\text { Workers }}{(4)}$ & $\frac{\text { Debt }}{(5)}$ \\
\hline \multicolumn{6}{|l|}{ A-Placebo in dictatorship } \\
\hline Direct link $\times$ After attempted murder of Pinochet & $\begin{array}{c}0.001 \\
(0.008)\end{array}$ & $\begin{array}{c}0.236 \\
(0.156)\end{array}$ & $\begin{array}{l}-0.314^{*} \\
(0.167)\end{array}$ & $\begin{array}{c}0.038 \\
(0.110)\end{array}$ & $\begin{array}{c}9.6 \\
(10.1)\end{array}$ \\
\hline Indirect link $\times$ After attempted murder of Pinochet & $\begin{array}{c}0.010 \\
(0.008)\end{array}$ & $\begin{array}{l}0.151^{* *} \\
(0.064)\end{array}$ & $\begin{array}{l}-0.084 \\
(0.110)\end{array}$ & $\begin{array}{l}-0.014 \\
(0.077)\end{array}$ & $\begin{array}{c}17.7 \\
(14.6)\end{array}$ \\
\hline $\begin{array}{l}\text { Firms } \\
\text { Observations }\end{array}$ & $\begin{array}{c}118 \\
1,518\end{array}$ & $\begin{array}{c}118 \\
1,400\end{array}$ & $\begin{array}{c}89 \\
310\end{array}$ & $\begin{array}{c}89 \\
310\end{array}$ & $\begin{array}{l}109 \\
829\end{array}$ \\
\hline \multicolumn{6}{|l|}{ B-Placebo in democracy } \\
\hline Direct link $\times$ After local/presidential elections & $\begin{array}{c}0.012 \\
(0.010)\end{array}$ & $\begin{array}{c}0.159 \\
(0.099)\end{array}$ & $\begin{array}{l}-0.501 \\
(0.315)\end{array}$ & $\begin{array}{c}0.085 \\
(0.090)\end{array}$ & $\begin{array}{c}-1.7 \\
(11.9)\end{array}$ \\
\hline Indirect link $\times$ After local/presidential elections & $\begin{array}{c}0.009 \\
(0.010)\end{array}$ & $\begin{array}{c}0.136 \\
(0.090)\end{array}$ & $\begin{array}{c}0.262 \\
(0.241)\end{array}$ & $\begin{array}{c}0.109 \\
(0.109)\end{array}$ & $\begin{array}{l}-8.1 \\
(8.5)\end{array}$ \\
\hline Firms & 118 & 118 & 92 & 92 & 109 \\
\hline Observations & 2,232 & 2,348 & 411 & 411 & 1,034 \\
\hline Firm and time F.E. & $\mathrm{x}$ & $\mathrm{x}$ & $\mathrm{x}$ & $\mathrm{x}$ & $\mathrm{x}$ \\
\hline Industry F.E. $\times$ Post & $\mathrm{x}$ & $\mathrm{x}$ & $\mathrm{x}$ & $\mathrm{x}$ & $\mathrm{x}$ \\
\hline
\end{tabular}

Notes: In panel A we create a placebo exercise by splitting the dictatorship period in two, before and after the third quarter of 1986, time when a group of individuals attempted to murder Pinochet. In panel B, we create another placebo by splitting the democracy period in two, before and after the 1993 presidential elections (1990-1997) in columns 1-2, and before and after 1992 local elections in columns 4-5. Robust standard errors are clustered at the business group level and are reported in parentheses (104 clusters). Significance level: ${ }^{* *} p<0.01,{ }^{* *} p<0.05, * p<0.1$. More details in section 4 . 


\section{Table 6: Firm entry}

Dependent variable is the logarithm of total number of firms in the period 1984-2000

\begin{tabular}{|c|c|c|c|c|}
\hline \multirow[b]{2}{*}{ A - All industries } & \multicolumn{2}{|c|}{ Share } & \multicolumn{2}{|c|}{ Indicator } \\
\hline & (1) & (2) & (3) & (4) \\
\hline Share of firms with links in $1987 \times$ Post & $\begin{array}{c}-0.44^{* *} \\
(0.19)\end{array}$ & $\begin{array}{l}-1.24 \\
(0.94)\end{array}$ & $\begin{array}{c}-0.24^{* * *} \\
(0.08)\end{array}$ & $\begin{array}{c}-0.63^{*} \\
(0.35)\end{array}$ \\
\hline $\begin{array}{l}\text { Industries } \\
\text { Observations }\end{array}$ & $\begin{array}{c}9 \\
153\end{array}$ & $\begin{array}{c}9 \\
153\end{array}$ & $\begin{array}{c}9 \\
153\end{array}$ & $\begin{array}{c}9 \\
153\end{array}$ \\
\hline B - Manufacturing & & & & \\
\hline Share of firms with links in $1987 \times$ Post & $\begin{array}{l}-4.31^{* * *} \\
(1.09)\end{array}$ & $\begin{array}{c}-10.78^{* * *} \\
(3.42)\end{array}$ & $\begin{array}{l}-0.06^{*} \\
(0.03)\end{array}$ & $\begin{array}{c}-0.22^{*} \\
(0.11)\end{array}$ \\
\hline Industries & 11 & 11 & 11 & 11 \\
\hline Observations & 176 & 176 & 176 & 176 \\
\hline Industry F.E. & $\mathrm{x}$ & $x$ & $\mathrm{x}$ & $\mathrm{x}$ \\
\hline Year F.E. & $\mathrm{x}$ & $\mathrm{x}$ & $\mathrm{x}$ & $\mathrm{x}$ \\
\hline Industry trend & $\mathrm{x}$ & $\mathrm{x}$ & $\mathrm{x}$ & $x$ \\
\hline Industry trend $\times$ Post & & $x$ & & $\mathrm{x}$ \\
\hline
\end{tabular}

Notes: Panel A uses data from the Superintendencia de Valores y Seguros and Panel B uses data from the manufacturing census of firms (ENIA). We define "Share of firms with links in 1987" in columns 1-2 as the percentage of firms in an industry that have a link to the regime in 1987. Columns 3-4 use an indicator for industries with a high share of links (above the median). Industry Trend is a linear trend for each industry. Robust standard errors are reported in parentheses. Significance level: ${ }^{* *} p<0.01,{ }^{* *} p<0.05,{ }^{*} p<0.1$. 


\section{For Online Publication}

\section{Losing Your Dictator: Firms During Political Transition}

Felipe González and Mounu Prem

\section{Contents}

A Theoretical Framework

A.1 Environment . . . . . . . . . . . . . . . . . . . . iii

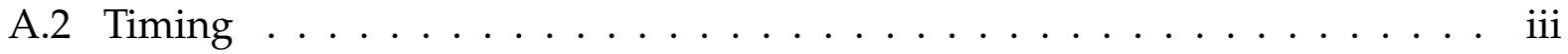

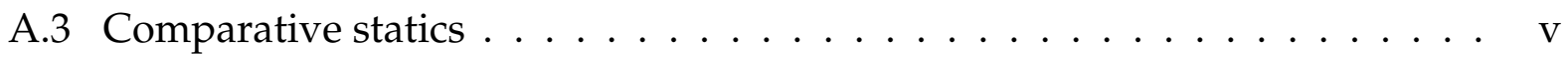

B Construction of links to the Pinochet regime viii

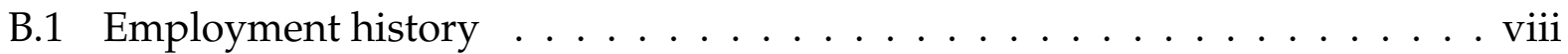

B.2 Descriptive statistics $\ldots \ldots \ldots \ldots \ldots \ldots \ldots$ ix

\section{List of Figures}

A.1 Political transitions in the world $1900-2010 \ldots \ldots \ldots \ldots$. . . . . . . .

A.2 Macroeconomic indicators $1980-2000 \ldots \ldots$. . . . . . . . . . . . . xi

A.3 Stock returns around other important political events . . . . . . . . . xii

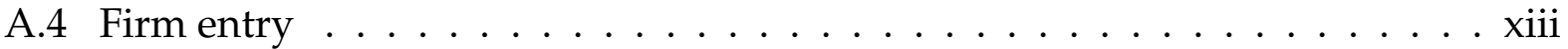

A.5 Firm investments during political transition . . . . . . . . . . xiv

\section{List of Tables}

A.1 Example of a firm with a direct link to Pinochet . . . . . . . . . xv

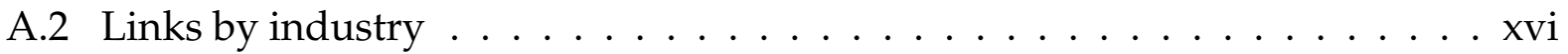

A.3 Stock returns after the 1988 plebiscite . . . . . . . . . . . . . . . . xvii

A.4 Firm outcomes during political transition $\ldots \ldots \ldots \ldots$. . . . . . xviii 
A.5 The credit market during political transition $\ldots \ldots \ldots \ldots$ xix

A.6 Other sources of funding $\ldots \ldots \ldots \ldots \ldots \ldots \ldots \ldots \ldots \ldots$

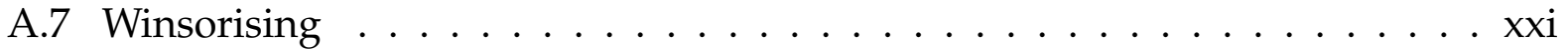

A.8 Solow productivity $\ldots \ldots \ldots \ldots \ldots \ldots \ldots \ldots \ldots \ldots \ldots$ xii

A.9 Links to the regime in $1986 \ldots \ldots \ldots$. . . . . . . . . . . . xxiii

A.10 Banks with links to the Pinochet regime $\ldots \ldots \ldots \ldots$. . . . . . xxiv

A.11 Substitution of links from the old to the new regime $\ldots \ldots \ldots \ldots x v$

A.12 Predicting direct and indirect links $\ldots \ldots \ldots \ldots \ldots$ xxvi $\ldots \ldots \ldots$

A.13 Synthetic controls . . . . . . . . . . . . . . . . . xxvii

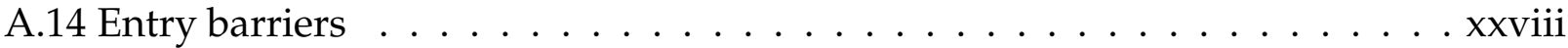

A.15 Extraordinary dividends . . . . . . . . . . . . . . xxix 


\section{A Theoretical Framework}

How do firms react to an announced political transition? how does this reaction vary with links to the incumbent regime? This section presents a theoretical framework to answer these questions. There are two key assumptions in our model. First, firms close to the non-democratic regime enjoy differential access to finance, which disappears after a democratization. Second, there is an increase in firm entry during the democratic period. The main insight we obtain is that increasing productive capacity becomes a dominant strategy for firms with links to the dictatorship during political transition.

\section{A.1 Environment}

Let there be $N_{t}$ incumbent firms and three different periods $t=1,2,3$. In the first period, a dictator is in power and $N_{1}$ firms operate in the market. In the second period, all firms learn that a new democratic government will take office in the third period. Following our setting, we assume this is an unanticipated democratization announcement. As it is public knowledge that the dictator will leave office, we call this period "transition." Potential entrants also learn about the political transition and update their entry decisions accordingly. We call the third period "democracy," where a newly democratically elected government rules the country and new firms enter the market.

In periods 1 and 2, firms can have different links to the dictator. There are not links to the democratic government in period 3. Let link of firm $i$ be represented by $\gamma_{i} \in$ $[0, r]$, where $\gamma_{i}=0$ represents no link, and $\gamma_{i}>0$ some link between a firm and the dictatorship. In each period, firms compete à la Cournot by choosing their input subject to a given private demand $Q_{t}=a-b P_{t}$. Let the production technology be $q_{t}^{i}=K_{t}^{i}$, where $K_{t}^{i}$ is the stock of capital of firm $i$ in period $t$. The marginal cost of producing one extra unit is zero if production is below a firm's capacity, and infinite otherwise.

The cost of capital for firms is $R_{i} \equiv r-\gamma_{i}$. We interpret this lower cost of capital as the combination of two factors: (1) firms with links have more access to credit, and (2) firms with links have relatively better information about investment opportunities. We will discuss how we can place bounds on these mechanisms exploiting the network analysis.

\section{A.2 Timing}

In period 1 , there are $N_{1}$ firms competing in quantities. Private demand for the homoge-

neous product is fixed. Firm $i$ chooses $K_{1}^{i}$ to maximize the discounted present value of 
profits, and expect the dictator to be ruling indefinitely. Then, a firm's problem is:

$$
\max _{K_{1}^{i}} \Pi_{1}^{i}=\frac{1}{1-\delta}\left[b^{-1}\left(a-\sum_{j}^{N_{1}} K_{1}^{j}\right) K_{1}^{i}-R_{i} K_{1}^{i}\right]
$$

where $\delta \in(0,1)$ represents the discount factor. Let the term in square brackets be denoted by $\Omega\left(K_{1}^{i}, N_{1} \mid \gamma_{i}\right)$ to facilitate exposition. For simplicity, let $\gamma_{i} \in\{0, \bar{\gamma}, r\}$, with $\bar{\gamma} \in(0, r)$. Then, there are three types of firms: direct link $\left(C: \gamma_{i}=r\right)$, indirect link $\left(I: \gamma_{i}=\bar{\gamma}\right)$, and without link $\left(U: \gamma_{i}=0\right)$. Thus, $i \in\{C, I, U\} .{ }^{1}$ To find the Nash equilibrium in dictatorship, we obtain firms best response function. Then, we use these best response functions to solve for productive capacities. Equilibrium capacities are:

$$
\begin{aligned}
K_{1}^{C} & =\frac{a+b(2 r-\bar{\gamma})}{4} \\
K_{1}^{I} & =\frac{a-b(2 r-3 \bar{\gamma})}{4} \\
K_{1}^{U} & =\frac{a-b(2 r+\bar{\gamma})}{4}
\end{aligned}
$$

Total quantity offered in the market is defined as $Q_{1}^{*}=\sum_{i \in\{C, I, U\}}^{N_{1}} K_{1}^{i}$. The equilibrium price is determined by the aggregate demand function, and profits are computed as in equation (1).

In period 2, firms learn that a democratization will take place with certainty. This means connected firms will lose their political links. Specifically, we assume:

Assumption 1. There is an exogenous democratization announcement.

Assumption 2. It is common knowledge that firm entry is exogenously higher in democracy.

Firms can adjust their productive capacity in the second period, when links are still in place. This could be a firm's optimal response in order to compete with new entrants. The new equilibrium is similar to the equilibrium of a Stackelberg game. In our case, incumbent firms are first movers and entrants are followers. Then, firms internalize future competition and solve the following problem:

$$
\max _{K_{2}^{i}} \Pi_{2}^{i}=\Omega\left(K_{2}^{i}, N_{2} \mid \gamma_{i}\right)+\frac{\delta}{(1-\delta)} \Omega\left(K_{2}^{i}, N_{3} \mid \gamma_{i}=0\right)
$$

\footnotetext{
${ }^{1}$ Note that firms do not expect a political transition to take place in the foreseeable future. Then, assuming that the free entry condition is binding, we can interpret this period as a steady state.
} 
where $N_{2}=N_{1}$ and $N_{3}$ is the number of firms operating in democracy. Then, equilibrium capacities for the period after the democratization announcement are:

$$
\begin{aligned}
K_{2}^{C} & =\frac{1}{4}\left(a+b\left(r+\frac{2(1+\psi)(r-\bar{\gamma})+2 \psi r}{2+\psi}\right)\right) \\
K_{2}^{I} & =\frac{1}{4}\left(a+b\left(r-\frac{6(1+\psi)(r-\bar{\gamma})-2 \psi r}{2+\psi}\right)\right) \\
K_{2}^{U} & =\frac{1}{4}\left(a+b\left(-3 r+\frac{2(1+\psi)(r-\bar{\gamma})-\psi r}{2+\psi}\right)\right) \\
K_{2}^{E} & =\frac{1}{8}\left(a+b\left(-3 r+\frac{2(1+\psi)(r-\bar{\gamma})-\psi r}{2+\psi}\right)\right)
\end{aligned}
$$

where $\psi \equiv \delta(1-\delta)^{-1}$. Then, total quantity offered in the market during transition and democratic periods are defined respectively by $Q_{2}^{*}=\sum_{i \in\{C, I, U\}}^{N_{2}} K_{2}^{i}$ and $Q_{3}^{*}=\sum_{i \in\{C, I, U, E\}}^{N_{3}} K_{3}^{i}$, where note that there are $N_{2}=N_{1}$ incumbent firms in the second period, and $N_{3}$ incumbent firms in the third period. Finally, the equilibrium price is determined by the aggregate demand function, and profits are computed as in equation (1).

In period 3, all links disappear (i.e., $\gamma_{i}=0 \forall i$ ), and production and entry decisions are decided as a function of the actions taken by incumbent firms in period 2. Former incumbent firms face the same objective function.

\section{A.3 Comparative statics}

Let $K_{t}^{i}$-the solution of the game- denote the capital stock of firm $i$ during period $t$. Then:

Proposition A.1. Under assumptions 1 and 2 capital adjustment is a dominant strategy. Firms with different links adjust differently:

$$
K_{2}^{C}>K_{1}^{C} ; K_{2}^{I} \lesseqgtr K_{1}^{I} ; K_{2}^{U}<K_{1}^{U}
$$

Exists $\gamma^{*} \in(0,1)$ s.t. if $\bar{\gamma}>\gamma^{*}$ then $K_{2}^{I}>K_{1}^{I}$, if $\bar{\gamma}<\gamma^{*}$ then $K_{2}^{I}<K_{1}^{I}$, and if $\bar{\gamma}=\gamma^{*}$ then $K_{2}^{I}=K_{1}^{I}$.

Proof: Using the equilibrium capacities, we can compare how capacity changes between periods 
for firms with different types of links. In the case of firms with direct links:

$$
K_{2}^{C}-K_{1}^{C}=\frac{\psi b}{4(2+\psi)}(3 r-\bar{\gamma})
$$

Note that if $\delta=0$, we have that $\psi=0$, then $K_{2}^{C}=K_{1}^{C}$. Therefore, if $\delta>0$, and $\bar{\gamma} \leq r$, we have that $(3 r-\bar{\gamma})>0$. This means that $K_{2}^{C}>K_{1}^{C}$. In the case of firms with indirect links, this inequality becomes ambiguous. To see this more clearly, let us subtract the equilibrium capacities for these firms in the two periods of interest:

$$
K_{2}^{I}-K_{1}^{I}=\frac{\psi b}{4(2+\psi)}(9 \bar{\gamma}-7 r)
$$

Note that if $\delta=0$, we have that $\psi=0$, then $K_{2}^{I}=K_{1}^{I}$. Therefore, if $\delta>0$, the difference of interest will be positive if and only if $(9 \bar{\gamma}-7 r)>0$. This means that if $\bar{\gamma}>\frac{7}{9} r$ we have that $K_{2}^{I}>K_{1}^{I}$, if $\bar{\gamma}=\frac{7}{9} r$ we have that $K_{1}^{I}=K_{2}^{I}$, and if $\bar{\gamma}<\frac{7}{9} r$ we have that $K_{2}^{I}<K_{1}^{I}$. Note that, $\gamma^{*}=\frac{7}{9} r$. Finally, firms without links decrease their productive capacity. To see this, let us again subtract the equilibrium capacities in the two periods of interest:

$$
K_{2}^{U}-K_{1}^{U}=-\frac{\psi b}{4(2+\psi)}(r+\bar{\gamma})
$$

Note that if $\delta=0$, we have that $\psi=0$, then $K_{2}^{U}=K_{1}^{U}$. Therefore, if $\delta>0$, we have that $(r+\bar{\gamma})>0$. This means that $K_{2}^{U}<K_{1}^{U}$.

Firms with links increase their capital stock in period 2 because of (i) the increase in firm entry in period 3 and (ii) the lower cost of capital they face. Firms without links adjust their capital stock downwards to keep prices high when new firms enter the market. A corollary of Proposition A.1 is:

$$
\underbrace{K_{2}^{C}-K_{1}^{C}}_{>0}>\underbrace{K_{2}^{I}-K_{1}^{I}}_{\gtreqless 0}>\underbrace{K_{2}^{U}-K_{1}^{U}}_{<0}
$$

In addition, to give us insights about mechanisms behind the lower cost of capital, the network analysis is useful. The lower cost of capital can be decomposed as $R-r=$ $\bar{\gamma}+(\gamma-\bar{\gamma})$. Recall that firms with direct and indirect links share board members, which implies that information flows freely among them. This means that their differential investment reaction places a bound to the role of information. Specifically, the higher the difference in investment between firms with direct and indirect links, the lower the role of information. 
The following proposition summarizes the predictions for profits:

Proposition A.2. Under assumptions 1 and 2, there exist $\bar{\gamma}$ such that profits are higher for firms with direct links during political transition:

$$
\Pi_{2}^{C}(\bar{\gamma})>\Pi_{1}^{C}(\bar{\gamma}) ; \Pi_{2}^{I}(\bar{\gamma})>\Pi_{1}^{I}(\bar{\gamma}) .
$$

Firms without links obtain decreasing profits $\forall \gamma, \Pi_{3}^{U}<\Pi_{2}^{U}<\Pi_{1}^{U}$.

Proof: Profits for firms with different types of links can be easily calculated from equilibrium capacities and the equilibrium price we computed in each period. Let us start by calculating the change in profits for firms with direct links. To do this, we need to take the difference between $\Pi_{2}^{C}$ and $\Pi_{1}^{C}$. Note that if $\delta=0, \Pi_{2}^{C}=\Pi_{1}^{C}$. Now let us assume $\delta>0$ and take the derivative of the difference in profits with respect to $\psi$ :

$$
\frac{\mathrm{d}\left(\Pi_{2}^{C}-\Pi_{1}^{C}\right)}{\mathrm{d} \psi}=\frac{1}{16 b}\left(\frac{4 b(a+b r)}{(2+\psi)^{2}}(r-\bar{\gamma})+\frac{8 b^{2} \psi}{(2+\psi)^{3}}\left((1-\psi) r^{2}+(1+\psi)(r-\bar{\gamma})^{2}\right)\right)
$$

where the last term in the big parenthesis is always positive because $\psi<1$. Then, given that $\psi$ is increasing in $\delta$, we can use the chain rule to conclude that $\Pi_{2}^{C}-\Pi_{1}^{C}$ increases with $\delta$. This means that as $\delta$ increases, $\Pi_{2}^{C}$ becomes larger than $\Pi_{1}^{C}$. Intuitively, the more linked firms value the future the more they are going to invest during political transition in order to deter entry in period 3, this will lead to an increase in their profits. To facilitate the proof for firms with indirect links, let us now move to the analysis of firms without links. Note that if $\delta=0$ we have that $K_{2}^{U}=K_{1}^{U}$ and $P_{2}=P_{1}$. Therefore, $\Pi_{2}^{U}=\Pi_{1}^{U}$. Assume that $\delta>0$. Then, it is easy to see that $P_{2}<P_{1}$ and $K_{2}^{U}<K_{1}^{U}$. Therefore, it follows that $\Pi_{2}^{U}<\Pi_{1}^{U}$. Firms without links do not have access to preferential credit which leads them to reduce their capital, reducing their profits. Using previous results, we can conclude that for any given $\delta>0$, if $\gamma \rightarrow 0$, the difference in profits converges to the one of firms without links, meaning that $\Pi_{2}^{I}<\Pi_{1}^{I}$. If $\gamma \rightarrow r$, on the other side, the difference in profits converges to the one of firms with direct links, which implies that $\Pi_{2}^{I}>\Pi_{1}^{I}$. Therefore, for any given $\delta$, there must be a $\bar{\gamma}$, such that for $\gamma>\bar{\gamma}$ the difference in profits is positive and for $\gamma<\bar{\gamma}$ is negative. Finally, since $P_{2}>P_{3}$, due to the entry of new firms, we conclude that $\Pi_{2}^{C}<\Pi_{3}^{C}, \Pi_{2}^{I}<\Pi_{3}^{I}, \Pi_{2}^{U}<\Pi_{3}^{U}$.

Two forces drive profits: prices and capacity. Prices decrease during periods 2 and 3 . Proposition A.2 shows that for some $\bar{\gamma}$, profits increase during period 2. In particular, the higher $\bar{\gamma}$, the lower the profits for firms with direct links during period 2, because a higher $\bar{\gamma}$ implies firms with indirect links increase their capacity by more, which lowers 
prices. A corollary of this proposition is:

$$
\Pi_{2}^{C}-\Pi_{1}^{C}>\Pi_{2}^{I}-\Pi_{1}^{I}>\Pi_{2}^{U}-\Pi_{1}^{U} .
$$

The difference in profits between the transition and democratic period, on the other hand, depends on the number of firms that enter the market in period 3 . The number of entrants could be driven by, for example, lower entry costs.

Some auxiliary predictions can be derived from the model. First, increases in capacity during political transition are associated with more profits during the democratic period. Second, capacity increases are a function of how capital intensive the industry is.

\section{B Construction of links to the Pinochet regime}

Section 2.1 of the paper presented our methodology to identify the network of firms with links to the Pinochet regime before the 1988 plebiscite. The outcomes of this methodology are direct (first degree) and indirect (second degree) links between publicly listed firms and Pinochet. Table A.1 presents an example of a firm with a direct link to the regime. As can be seen from this table, firms are linked because a subset of their board of directors worked for the Pinochet dictatorship. To uncover this labor relations, we searched for the employment history of the universe of board members working in 1987 at firms listed in the Chilean stock market. This section presents more details about our identification of labor relations.

\section{B.1 Employment history}

Investigation of the employment history of board members before 1988 is possible due to the vast amount of information available online about individuals that worked for the Pinochet dictatorship. We gathered this information using Google as an oracle for standardized queries. We performed searches in incognito mode to avoid personalized searches and facilitate replication. More precisely, we look in the first page of results using two different queries:

1. Full name of board member

2. Full name of board member + Pinochet

Empirically, several reports document the name and specific job that people performed during the dictatorship (e.g., "Los 100 rostros de la dictadura", "Memoria Viva," among 
others). In addition, heads of government departments and army officers are extremely well known and, consequently, have an employment history that is easy to track.

\section{B.2 Descriptive statistics}

We found that 78 board members (approximately 10 percent) had a direct link to Pinochet in 1987. These board members had different jobs in the dictatorship: 22 were army officers, 9 were close (economic or legal) advisors, 24 worked as head of government departments (ministers), 19 worked as politicians (e.g. local politicians), 2 were part of Pinochet's family, and 2 collaborated with money and press.

\section{References}

Abadie, A., Diamond, A., and Hainmueller, J. (2010). Synthetic control methods for comparative case studies: estimating the effect of California's tobacco control program. Journal of the American Statistical Association, 105(490):493-505.

Abadie, A. and Gardeazabal, J. (2003). The economic costs of conflict: a case study of the Basque country. American Economic Review, 93(1):113-132.

Acemoglu, D. (2008). Oligarchic versus democratic societies. Journal of the European Economic Association, 6(1):1-44.

CEME (2004). Informe de la comisión investigadora encargada de analizar presuntas irregularidades en las privatizaciones de empresas del estado ocurridas con anterioridad al año 1990. Centro de Estudios Miguel Enriquez.

Cingano, F. and Pinotti, P. (2013). Politicians at work: the private returns and social costs of political connections. Journal of the European Economic Association, 11(2):433-465.

Claessens, S., Feijen, E., and Laeven, L. (2008). Political connections and preferential access to finance: the role of campaign contributions. Journal of Financial Economics, 88:554-580.

Díaz, J., Lüders, R., and Wagner, G. (2016). Chile 1810-2010. La República en cifras. Historical statistics. Ediciones Universidad Católica de Chile.

Khwaja, A. I. and Mian, A. (2005). Do lenders favor politically connected firms? Rent provision in an emerging financial market. Quarterly Journal of Economics, 120(4):13711411. 
Figure A.1: Political transitions in the world 1900-2010

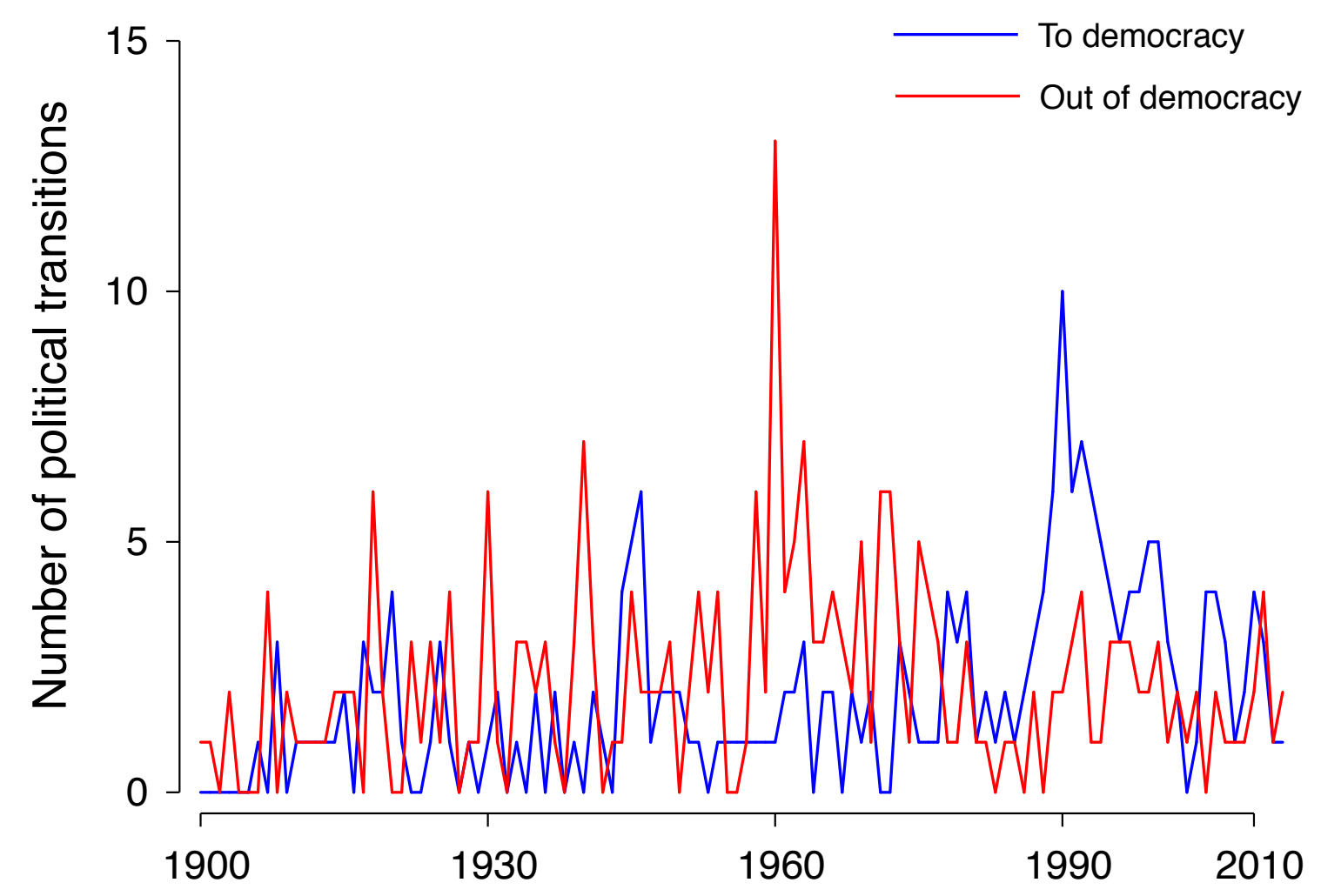

Notes: Own construction based on data from the Polity IV Project "Political Regime Characteristics and Transitions, 1800-2013." We define the year of a transition to democracy as a positive value of the variable democ in year $t$ and in the set $[-88,-77,-66,0]$ in year $t-1$, and the year of a transition out of democracy in the opposite way. 
Figure A.2: Macroeconomic indicators 1980-2000

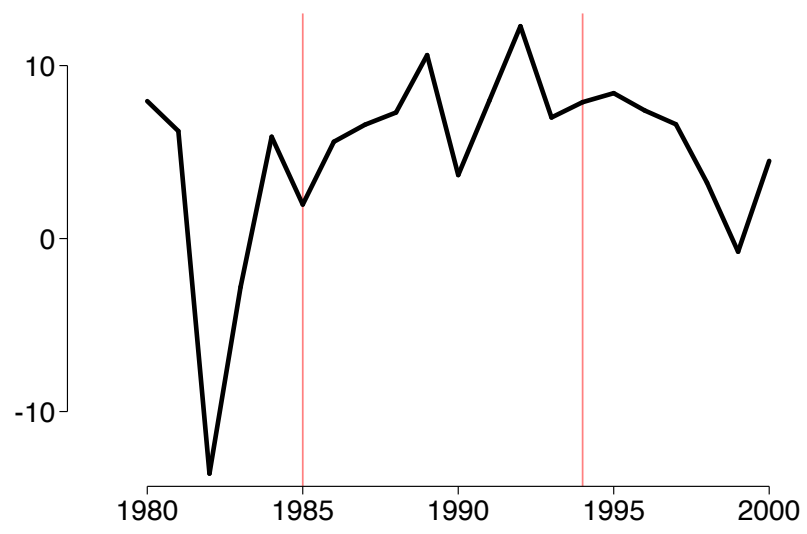

(a) GDP growth (\%)

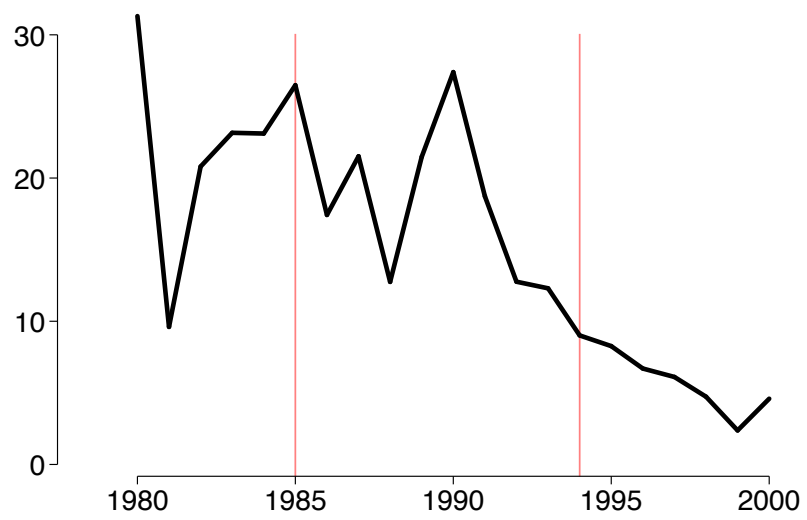

(c) Inflation (\%)

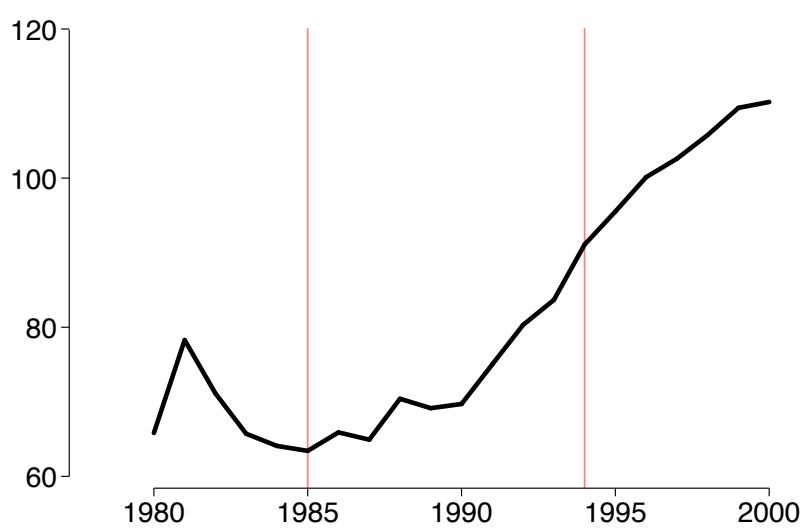

(e) Wage index

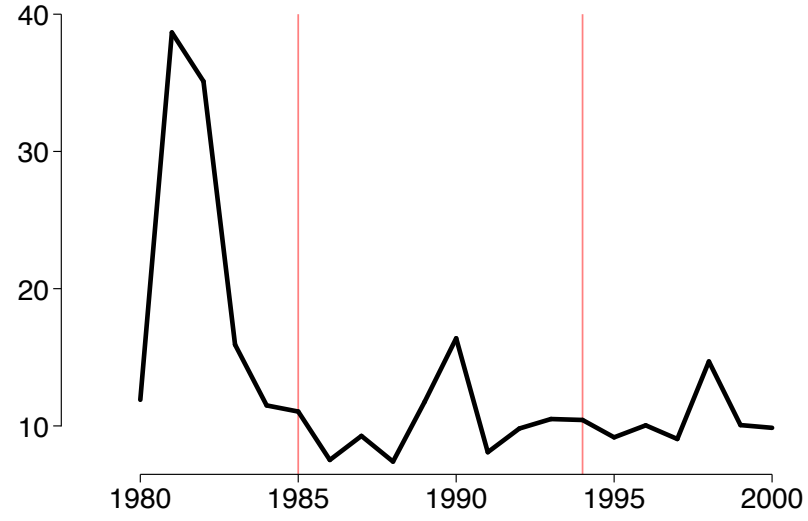

(b) Interest rate (\%)

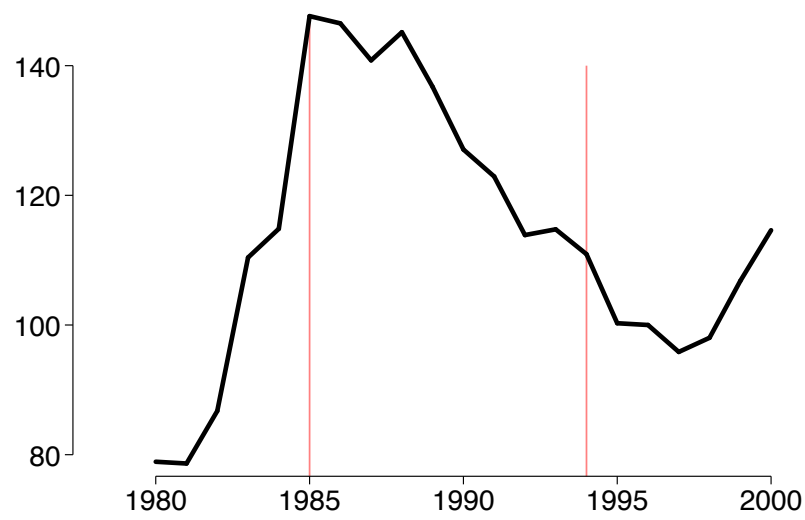

(d) Exchange rate

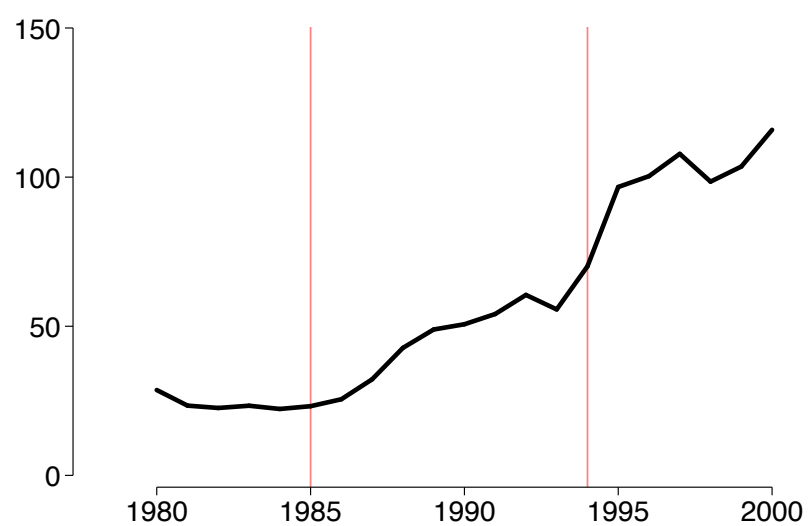

(f) Exports

Notes: Own construction based on data by Díaz et al. (2016). Vertical red lines denote the first and last year in our firm-level data. 
Figure A.3: Stock returns around other important political events
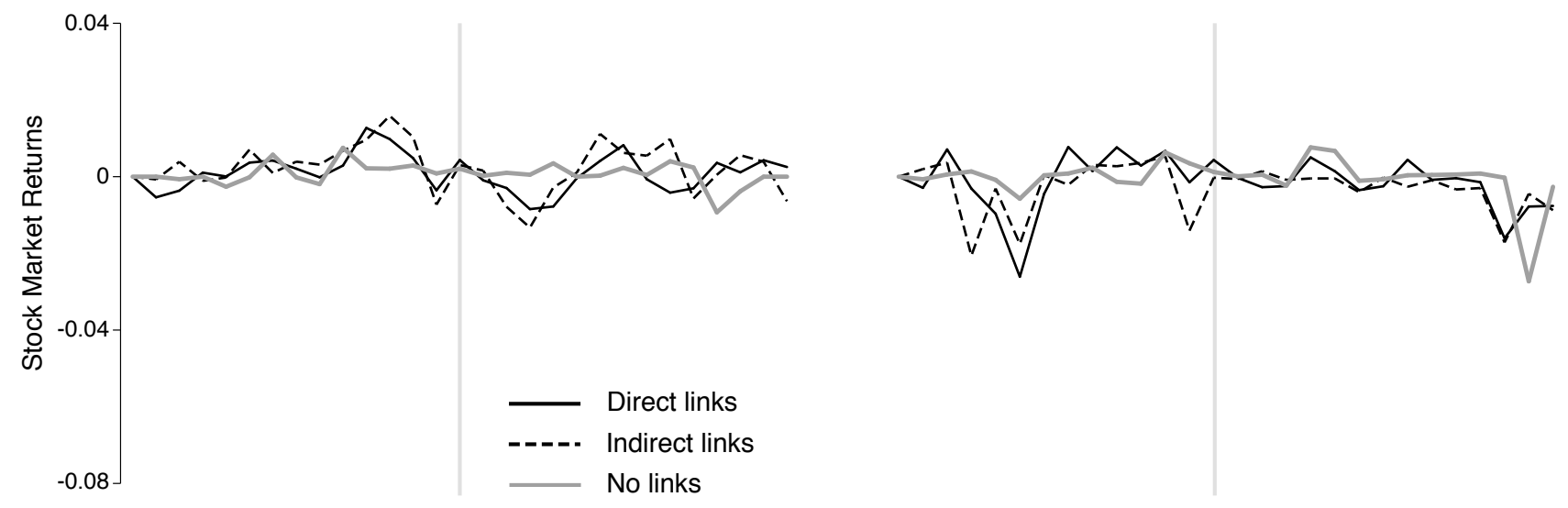

(a) Pinochet's nomination $(08 / 30 / 1988)$

(b) Constitutional reform $(07 / 28 / 1989)$
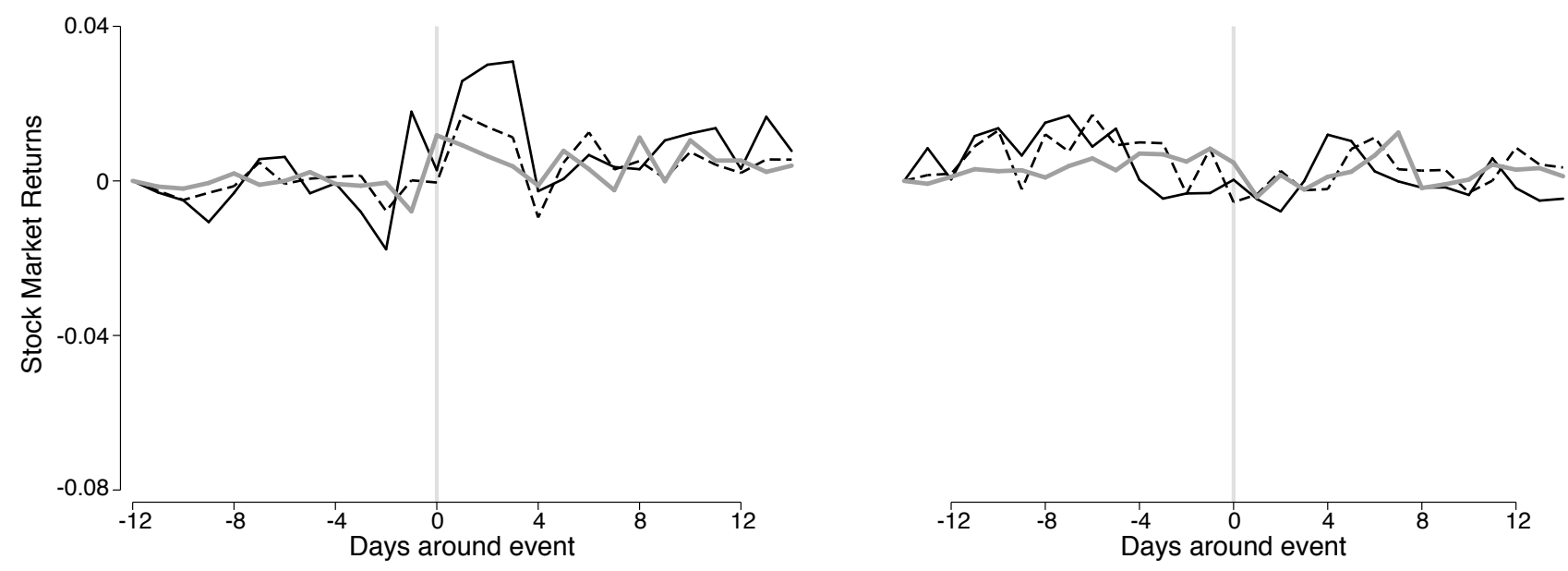

(c) Presidential election $(12 / 13 / 1989)$

(d) Pinochet leaves power $(11 / 03 / 1990)$

Notes: Own construction based on daily stock data from contemporary newspapers. We define stock returns as $R_{i t} \equiv$ $\ln S_{i t}-\ln S_{i t-1}$, where $S_{i t}$ is stock price $i$ in day $t$. More details in section 2.2. 
Figure A.4: Firm entry

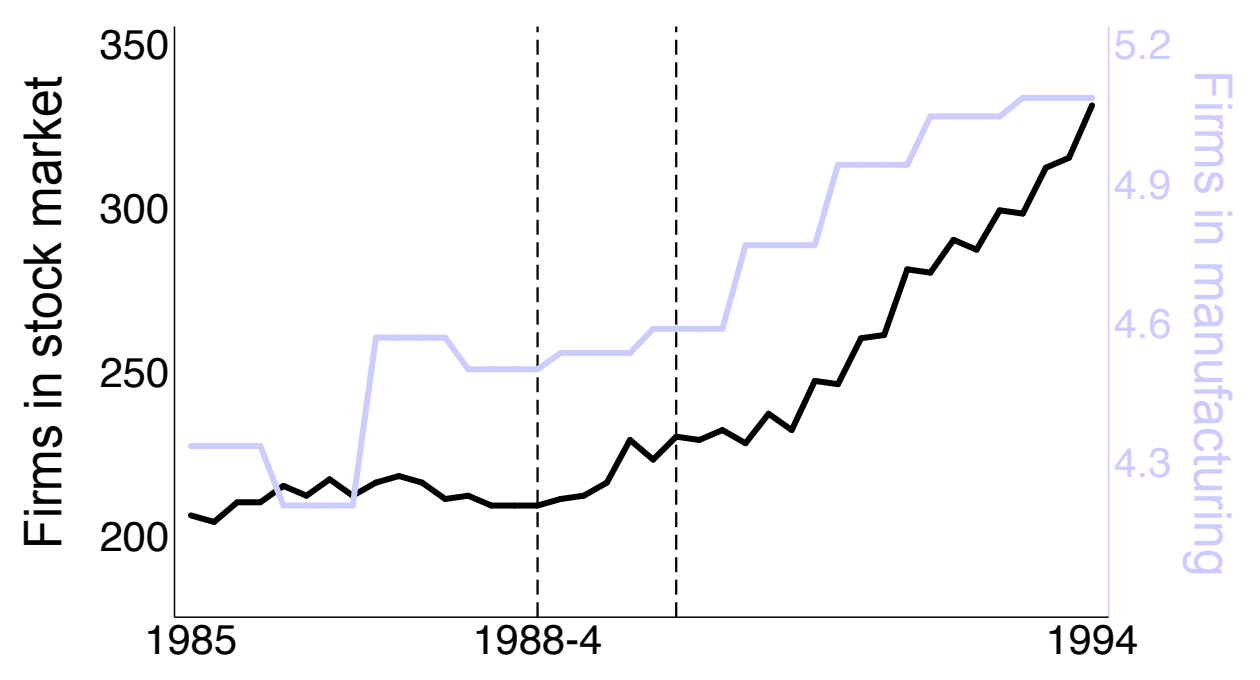

Notes: This figure presents the number of firms operating in the stock market during the period under study. Vertical dash lines represent the time of the plebiscite and the beginning of the democratic period (March 11th, 1990). The second y-axis (gray) presents the number of firms operating in the manufacturing census (Encuesta Nacional de la Industria Manufacturera, ENIA). 


\section{Figure A.5: Firm investments during political transition}
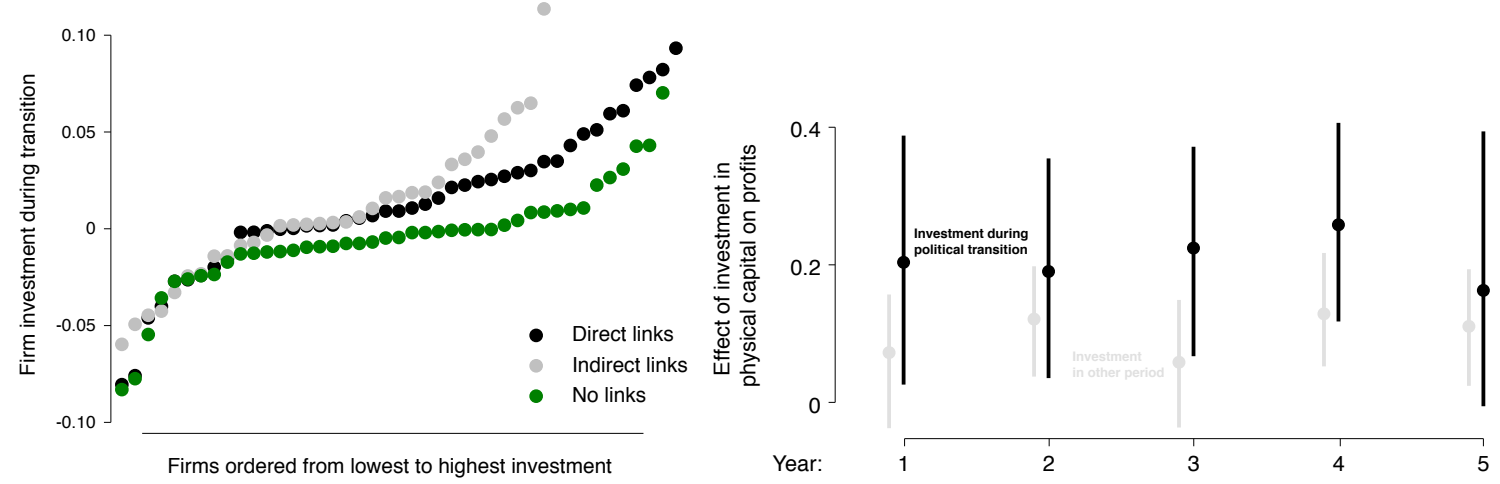

(a) Firm specific investments during (b) Investment during transition and profits in political transition democracy

Notes: Panel (a) presents estimates of firm-level investments changes in productive capacity during the transition period (1988-1990). Panel (b) presents the estimated relationship between investment during political transition and profits in the first five years of democracy. Details are as follows. We estimate the correlation between profits and firm-specific capacity responses during political transition. Because investments are expected to increase profits (at least on average), we compare the profits response to investments during political transition to the profits response to investments in the $3 r d$ quarter of 1986. We proceed in three steps. First, to estimate firm-specific responses, we augment equation (1) by interacting time period indicators with firm specific indicators. This allow us to estimate firm specific capacity responses $\beta_{i, \text { lame }}$ with $i=1, \ldots, 118$. Panel (a) plots these coefficients. Second, we construct profits in year $t$ by adding up quarterly profits. Third, we estimate the following cross-sectional regression each year between 1990 and 1994:

$$
\Pi_{i t}=\alpha_{t}+\tau_{t} \widehat{\beta}_{i, \text { lame }}+\eta_{i t}
$$

where $\Pi_{i t}$ represents profits in year $t$ for firm $i, \alpha_{t}$ is a constant term, and $\widehat{\beta}_{i, l a m e}$ is our estimate of firm-specific capacity responses. To facilitate the interpretation of coefficients, we have standardized capacity responses and yearly profits. The coefficient of interest is $\tau_{t}$, and our theoretical framework implies that $\tau_{t}>0$. Standard errors for $\tau_{t}$ are calculated using a bootstrap procedure to account for the uncertainty in our estimation of firm-specific capacity responses. Panel (b) presents OLS estimates of coefficients $\left(\hat{\tau}_{1990}, \ldots, \hat{\tau}_{1994}\right)$. 
Table A.1: Example of a firm with a direct link to Pinochet

\begin{tabular}{|c|c|c|}
\hline Name of board member & Job in the Pinochet regime & Years in job \\
\hline Guillermo Letelier & Army Officer & 1980s \\
\hline Sergio Melnik & Minister of Planning & 1987 \\
\hline Julio Ponce Lerou & Pinochet's son in law & $1969-$ \\
\hline Enrique Valenzuela & Minister of Mining & 1975-1978 \\
\hline Sergio Valenzuela & Minister of Planning & 1985 \\
\hline Nine other board members & No links & - \\
\hline
\end{tabular}

Notes: Names and links of individuals working in the Board of Directors of the Chemical and Mining Society of Chile in 1987, a Chilean chemical company and supplier of industrial chemicals. Board members data comes from Superintendencia de Valores y Seguros. More details in section 2.1 and section B. 
Table A.2: Links by industry

\begin{tabular}{|c|c|c|c|c|}
\hline Industry: & No links & $\begin{array}{l}\text { Direct links } \\
\text { to Pinochet }\end{array}$ & $\begin{array}{c}\text { Indirect links } \\
\text { to Pinochet }\end{array}$ & $\begin{array}{l}\text { Total number } \\
\text { of firms }\end{array}$ \\
\hline Accommodation and food service activities & 0 & 2 & 1 & 3 \\
\hline Agriculture, forestry, and fishing & 3 & 4 & 8 & 15 \\
\hline Arts, entertainment, and recreation & 0 & 1 & 0 & 1 \\
\hline Construction & 2 & 1 & 0 & 3 \\
\hline Education & 1 & 0 & 0 & 1 \\
\hline Electricity, gas, steam and air conditioning supply & 4 & 6 & 2 & 12 \\
\hline Human health and social work activities & 1 & 0 & 0 & 1 \\
\hline Information and communication & 0 & 2 & 2 & 4 \\
\hline Manufacturing & 13 & 19 & 13 & 45 \\
\hline Mining and quarrying & 2 & 3 & 2 & 7 \\
\hline Real estate activities & 14 & 1 & 3 & 18 \\
\hline Transportation and storage & 1 & 3 & 1 & 5 \\
\hline Wholesale and retail trade & 1 & 1 & 1 & 3 \\
\hline Total: & 42 & 43 & 33 & 118 \\
\hline
\end{tabular}

Notes: Number of firms by industry and type of link in our data. Own construction based on information in annual reports. 
Table A.3: Stock returns after the 1988 plebiscite

Dependent variable is cumulative abnormal stock returns

\begin{tabular}{|c|c|c|c|}
\hline Days after event: & Same day & $0-5$ days & 0-10 days \\
\hline Direct link & $\begin{array}{c}-0.05^{* * *} \\
(0.02)\end{array}$ & $\begin{array}{c}-0.08^{* * *} \\
(0.02)\end{array}$ & $\begin{array}{c}-0.07^{* * *} \\
(0.03)\end{array}$ \\
\hline Indirect link & $\begin{array}{c}-0.05^{* *} \\
(0.01)\end{array}$ & $\begin{array}{c}-0.08^{* * *} \\
(0.02)\end{array}$ & $\begin{array}{c}-0.10^{* * *} \\
(0.03)\end{array}$ \\
\hline Firms & 80 & 80 & 80 \\
\hline
\end{tabular}

Notes: This table shows a estimates from a cross section regression of abnormal cumulative stock returns on links to the Pinochet regime. Robust standard errors are reported in parentheses. Significance level: ${ }^{* * *} p<0.01,{ }^{* *} p<0.05$. 
Table A.4: Firm outcomes during political transition

\begin{tabular}{|c|c|c|c|c|c|c|}
\hline \multirow[b]{2}{*}{ Panel A } & (1) & $(2)$ & (3) & (4) & (5) & (6) \\
\hline & \multicolumn{3}{|c|}{ Investment } & \multicolumn{3}{|c|}{ Profits } \\
\hline Direct link $\times$ Transition & $\begin{array}{c}0.012 \\
(0.007)\end{array}$ & $\begin{array}{l}0.018^{* *} \\
(0.007)\end{array}$ & $\begin{array}{l}0.018^{* *} \\
(0.008)\end{array}$ & $\begin{array}{c}0.308^{* * * *} \\
(0.099)\end{array}$ & $\begin{array}{c}0.350^{* * *} \\
(0.099)\end{array}$ & $\begin{array}{r}0.290^{* * *} \\
(0.100)\end{array}$ \\
\hline Direct link $\times$ Democracy & $\begin{array}{l}0.011^{*} \\
(0.006)\end{array}$ & $\begin{array}{l}0.020^{* *} \\
(0.006)\end{array}$ & $\begin{array}{c}0.020^{* * *} \\
(0.007)\end{array}$ & $\begin{array}{c}0.197 \\
(0.128)\end{array}$ & $\begin{array}{l}0.254^{*} \\
(0.135)\end{array}$ & $\begin{array}{c}0.194 \\
(0.124)\end{array}$ \\
\hline Indirect link $\times$ Transition & & $\begin{array}{c}0.013 \\
(0.008)\end{array}$ & $\begin{array}{c}0.014 \\
(0.009)\end{array}$ & & $\begin{array}{l}0.096^{* *} \\
(0.044)\end{array}$ & $\begin{array}{l}0.115^{*} \\
(0.069)\end{array}$ \\
\hline Indirect link $\times$ Democracy & & $\begin{array}{l}0.019^{* *} \\
(0.008)\end{array}$ & $\begin{array}{l}0.020^{* *} \\
(0.008)\end{array}$ & & $\begin{array}{c}0.129 \\
(0.127)\end{array}$ & $\begin{array}{c}0.147 \\
(0.095)\end{array}$ \\
\hline $\begin{array}{l}\text { Firms } \\
\text { Observations } \\
\text { Firm and time F.E. } \\
\text { Industry F.E. } \times \text { Post }\end{array}$ & $\begin{array}{c}118 \\
4,694 \\
x\end{array}$ & $\begin{array}{c}118 \\
4,694 \\
x\end{array}$ & $\begin{array}{l}118 \\
4,694 \\
x \\
x\end{array}$ & $\begin{array}{c}118 \\
4,692 \\
x\end{array}$ & $\begin{array}{c}118 \\
4,692 \\
x\end{array}$ & $\begin{array}{l}118 \\
4,692 \\
x \\
x\end{array}$ \\
\hline Panel B & & Productivit & & & og workers & \\
\hline Direct link $\times$ Transition & $\begin{array}{c}0.046 \\
(0.158)\end{array}$ & $\begin{array}{l}-0.068 \\
(0.174)\end{array}$ & $\begin{array}{l}-0.065 \\
(0.177)\end{array}$ & $\begin{array}{c}0.022 \\
(0.106)\end{array}$ & $\begin{array}{c}0.020 \\
(0.106)\end{array}$ & $\begin{array}{c}0.028 \\
(0.108)\end{array}$ \\
\hline Direct link $\times$ Democracy & $\begin{array}{c}0.009 \\
(0.314)\end{array}$ & $\begin{array}{l}-0.013 \\
(0.345)\end{array}$ & $\begin{array}{c}0.130 \\
(0.376)\end{array}$ & $\begin{array}{l}-0.040 \\
(0.110)\end{array}$ & $\begin{array}{l}-0.016 \\
(0.116)\end{array}$ & $\begin{array}{l}-0.057 \\
(0.104)\end{array}$ \\
\hline Indirect link $\times$ Transition & & $\begin{array}{l}-0.224^{*} \\
(0.119)\end{array}$ & $\begin{array}{l}-0.230^{*} \\
(0.118)\end{array}$ & & $\begin{array}{c}-0.006 \\
(0.089)\end{array}$ & $\begin{array}{c}-0.004 \\
(0.089)\end{array}$ \\
\hline Indirect link $\times$ Democracy & & $\begin{array}{l}-0.043 \\
(0.214)\end{array}$ & $\begin{array}{l}-0.017 \\
(0.229)\end{array}$ & & $\begin{array}{c}0.044 \\
(0.111)\end{array}$ & $\begin{array}{c}0.048 \\
(0.110)\end{array}$ \\
\hline Firms & 99 & 99 & 99 & 99 & 99 & 99 \\
\hline Observations & 792 & 792 & 792 & 792 & 792 & 792 \\
\hline Firm and time F.E. & $\mathrm{x}$ & $\mathrm{x}$ & $\mathrm{x}$ & $\mathrm{x}$ & $x$ & $x$ \\
\hline Industry F.E. $\times$ Post & & & $\mathrm{x}$ & & & $x$ \\
\hline
\end{tabular}

Notes: Panel A uses a quarterly data and Panel B uses annual data. Both panels use data for the period 1985-1994. Robust standard errors are clustered at the business group level and are reported in parentheses. There are 104 clusters in Panel A and 88 clusters in Panel B. Significance level: *** $p<0.01,{ }^{* *} p<0.05,{ }^{*} p<0.1$. More details in section ??. 
Table A.5: The credit market during political transition

Dependent variable (Debt) is total debt with banks, measured from annual reports

\begin{tabular}{|c|c|c|c|c|c|c|c|c|c|}
\hline & \multicolumn{3}{|c|}{ Debt } & \multicolumn{3}{|c|}{$\begin{array}{l}\text { Indicator for } \\
\text { positive debt }\end{array}$} & \multicolumn{3}{|c|}{$\begin{array}{c}\text { Debt } \\
\text { over assets }\end{array}$} \\
\hline & $(1)$ & $(2)$ & (3) & $(4)$ & (5) & (6) & $(7)$ & $(8)$ & (9) \\
\hline Direct link $\times$ Transition $\times$ State bank & $\begin{array}{c}16.7 \\
(12.9)\end{array}$ & $\begin{array}{c}29.8^{* * *} \\
(10.2)\end{array}$ & $\begin{array}{c}29.8^{* * *} \\
(10.2)\end{array}$ & $\begin{array}{l}0.16^{* *} \\
(0.07)\end{array}$ & $\begin{array}{l}0.20^{* *} \\
(0.08)\end{array}$ & $\begin{array}{l}0.20^{* *} \\
(0.08)\end{array}$ & $\begin{array}{l}0.06^{* *} \\
(0.03)\end{array}$ & $\begin{array}{l}0.08^{* *} \\
(0.03)\end{array}$ & $\begin{array}{l}0.08^{* *} \\
(0.03)\end{array}$ \\
\hline Direct link $\times$ Democracy $\times$ State bank & $\begin{array}{c}-3.7 \\
(16.0)\end{array}$ & $\begin{array}{c}4.5 \\
(14.9)\end{array}$ & $\begin{array}{c}4.5 \\
(15.0)\end{array}$ & $\begin{array}{c}0.15 \\
(0.10)\end{array}$ & $\begin{array}{l}0.22^{* *} \\
(0.09)\end{array}$ & $\begin{array}{l}0.22 * * \\
(0.09)\end{array}$ & $\begin{array}{c}0.04 \\
(0.03)\end{array}$ & $\begin{array}{l}0.07^{*} \\
(0.04)\end{array}$ & $\begin{array}{l}0.07^{*} \\
(0.04)\end{array}$ \\
\hline Indirect link $\times$ Democracy $\times$ State bank & & $\begin{array}{l}17.0 \\
(19.5)\end{array}$ & $\begin{array}{c}17.2 \\
(19.5)\end{array}$ & & $\begin{array}{c}0.14 \\
(0.09)\end{array}$ & $\begin{array}{c}0.14 \\
(0.09)\end{array}$ & & $\begin{array}{c}0.06 \\
(0.05)\end{array}$ & $\begin{array}{c}0.06 \\
(0.05)\end{array}$ \\
\hline Double interactions & $\mathrm{x}$ & $\mathrm{x}$ & $\mathrm{x}$ & $\mathrm{x}$ & $\mathrm{x}$ & $\mathrm{x}$ & $\mathrm{x}$ & $\mathrm{x}$ & $\mathrm{x}$ \\
\hline Firm-bank F.E. & $x$ & $x$ & $x$ & $x$ & $x$ & $x$ & $x$ & $x$ & $x$ \\
\hline Year F.E. & $x$ & $x$ & $x$ & $x$ & $x$ & $x$ & $x$ & $x$ & $x$ \\
\hline Industry F.E. $\times$ Post & $x$ & $x$ & $x$ & $x$ & $x$ & $x$ & $x$ & $x$ & $x$ \\
\hline
\end{tabular}

Notes: These regressions use the annual dataset of firms in the period 1985-1994. The unit of observation is a firm-bank relationship per year. Double interactions include "period and bank" interaction terms, and "link type and period" interaction terms. Robust standard errors are clustered at the business group level and are reported in parentheses. The number of clusters is 99. Significance level: ${ }^{* * *} p<0.01,^{* *} p<0.05,{ }^{*} p<0.1$. More details in section ??. 


\section{Table A.6: Other sources of funding}

Dependent variable: issuance (total amount issued in shares and bonds) or an indicator for issuance greater than zero

\begin{tabular}{|c|c|c|c|c|c|c|}
\hline & \multicolumn{3}{|c|}{ Shares } & \multicolumn{3}{|c|}{ Bonds } \\
\hline & Issuance & $\mathbb{1}[$ Issuance $>0]$ & $\log ($ Issuance $)$ & Issuance & $\mathbb{1}[$ Issuance $>0]$ & $\log ($ Issuance $)$ \\
\hline & $(1)$ & $(2)$ & (3) & $(4)$ & (5) & (6) \\
\hline Direct link $\times$ Transition & $\begin{array}{l}-28.60 \\
(59.34)\end{array}$ & $\begin{array}{c}0.00 \\
(0.04)\end{array}$ & $\begin{array}{c}-9.01^{* * *} \\
(2.38)\end{array}$ & $\begin{array}{c}2.83 \\
(2.21)\end{array}$ & $\begin{array}{c}0.02 \\
(0.04)\end{array}$ & $\begin{array}{l}1.63^{*} \\
(0.94)\end{array}$ \\
\hline Direct link $\times$ Democracy & $\begin{array}{c}198.34 \\
(158.07)\end{array}$ & $\begin{array}{c}0.08 \\
(0.05)\end{array}$ & $\begin{array}{l}-2.92^{* *} \\
(1.14)\end{array}$ & $\begin{array}{l}2.27^{*} \\
(1.15)\end{array}$ & $\begin{array}{l}-0.03 \\
(0.03)\end{array}$ & $\begin{array}{l}- \\
-\end{array}$ \\
\hline Indirect link $\times$ Transition & $\begin{array}{l}118.57 \\
(99.92)\end{array}$ & $\begin{array}{c}0.07 \\
(0.05)\end{array}$ & $\begin{array}{l}-2.52^{* *} \\
(0.97)\end{array}$ & $\begin{array}{c}0.19 \\
(0.62)\end{array}$ & $\begin{array}{c}0.05 \\
(0.04)\end{array}$ & $\begin{array}{l}0.29^{* *} \\
(0.13)\end{array}$ \\
\hline Indirect link $\times$ Democracy & $\begin{array}{c}9.83 \\
(58.19)\end{array}$ & $\begin{array}{c}0.12^{* * *} \\
(0.05)\end{array}$ & $\begin{array}{c}-3.69^{* * *} \\
(0.74)\end{array}$ & $\begin{array}{c}0.62 \\
(0.72)\end{array}$ & $\begin{array}{l}0.05^{*} \\
(0.03)\end{array}$ & - \\
\hline Firms & 112 & 112 & 53 & 112 & 112 & 29 \\
\hline Observations & 1,107 & 1,107 & 100 & 1,107 & 1,107 & 54 \\
\hline Firm and time F.E. & $\mathrm{x}$ & $\mathrm{x}$ & $\mathrm{x}$ & $\mathrm{x}$ & $\mathrm{x}$ & $x$ \\
\hline Industry F.E. $\times$ Post & $x$ & $\mathrm{x}$ & $\mathrm{x}$ & $x$ & $x$ & $x$ \\
\hline
\end{tabular}

Notes: Data for firms in the period 1985-1994. Issuances are measured in \$MMM Chilean pesos. Robust standard errors are clustered at the business group level and are reported in parentheses. In columns 1, 2, 4, and 5, the number of clusters is 98; in column 3 (6) is 48 (28). Significance level: ${ }^{* * *} p<0.01,{ }^{* *} p<0.05,{ }^{*} p<0.1$. 
Table A.7: Winsorising

\begin{tabular}{|c|c|c|c|c|c|c|c|c|c|c|}
\hline \multirow{3}{*}{ Winsorized at: } & \multicolumn{2}{|c|}{ Investment } & \multicolumn{2}{|c|}{ Profits } & \multicolumn{2}{|c|}{ Productivity } & \multicolumn{2}{|c|}{ Workers } & \multicolumn{2}{|c|}{ Debt } \\
\hline & $1 \%$ & $5 \%$ & $1 \%$ & $5 \%$ & $1 \%$ & $5 \%$ & $1 \%$ & $5 \%$ & $1 \%$ & $5 \%$ \\
\hline & (1) & (2) & (3) & (4) & (5) & (6) & (7) & (8) & (9) & (10) \\
\hline Direct link $\times$ Transition & $\begin{array}{c}0.024 \\
(0.016)\end{array}$ & $\begin{array}{l}0.014^{* *} \\
(0.006)\end{array}$ & $\begin{array}{l}0.338^{* *} \\
(0.134)\end{array}$ & $\begin{array}{l}0.338^{* *} \\
(0.134)\end{array}$ & $\begin{array}{c}-0.003 \\
(0.249)\end{array}$ & $\begin{array}{l}-0.089 \\
(0.139)\end{array}$ & $\begin{array}{c}0.025 \\
(0.108)\end{array}$ & $\begin{array}{c}0.031 \\
(0.107)\end{array}$ & $\begin{array}{c}48.62^{* * *} \\
(15.60)\end{array}$ & $\begin{array}{c}21.86^{* * *} \\
(7.82)\end{array}$ \\
\hline Direct link $\times$ Democracy & $\begin{array}{c}0.039^{* * *} \\
(0.012)\end{array}$ & $\begin{array}{l}0.012^{* *} \\
(0.005)\end{array}$ & $\begin{array}{c}0.253^{*} \\
(0.135)\end{array}$ & $\begin{array}{c}0.253^{*} \\
(0.135)\end{array}$ & $\begin{array}{c}0.303 \\
(0.408)\end{array}$ & $\begin{array}{c}0.035 \\
(0.257)\end{array}$ & $\begin{array}{c}-0.058 \\
(0.103)\end{array}$ & $\begin{array}{c}-0.052 \\
(0.104)\end{array}$ & $\begin{array}{c}46.51 \\
(42.59)\end{array}$ & $\begin{array}{c}1.84 \\
(10.54)\end{array}$ \\
\hline Indirect link $\times$ Transition & $\begin{array}{c}0.018 \\
(0.015)\end{array}$ & $\begin{array}{c}0.010 \\
(0.006)\end{array}$ & $\begin{array}{c}0.103 \\
(0.070)\end{array}$ & $\begin{array}{c}0.103 \\
(0.070)\end{array}$ & $\begin{array}{c}-0.216^{*} \\
(0.119)\end{array}$ & $\begin{array}{c}-0.244^{* *} \\
(0.113)\end{array}$ & $\begin{array}{c}-0.004 \\
(0.089)\end{array}$ & $\begin{array}{c}0.012 \\
(0.089)\end{array}$ & $\begin{array}{c}77.77 \\
(65.91)\end{array}$ & $\begin{array}{c}15.21 \\
(10.04)\end{array}$ \\
\hline Indirect link $\times$ Democracy & $\begin{array}{c}0.033^{* * *} \\
(0.012)\end{array}$ & $\begin{array}{l}0.014^{* *} \\
(0.006)\end{array}$ & $\begin{array}{c}0.117 \\
(0.086)\end{array}$ & $\begin{array}{c}0.117 \\
(0.086)\end{array}$ & $\begin{array}{c}0.050 \\
(0.257)\end{array}$ & $\begin{array}{l}-0.056 \\
(0.204)\end{array}$ & $\begin{array}{c}0.048 \\
(0.110)\end{array}$ & $\begin{array}{c}0.059 \\
(0.109)\end{array}$ & $\begin{array}{c}48.83 \\
(46.78)\end{array}$ & $\begin{array}{c}8.21 \\
(10.67)\end{array}$ \\
\hline Firms & 118 & 118 & 118 & 118 & 99 & 99 & 99 & 99 & 112 & 112 \\
\hline Observations & 4,694 & 4,694 & 4,692 & 4,692 & 792 & 792 & 792 & 792 & 2,073 & 2,073 \\
\hline Firm and time F.E. & $\mathrm{x}$ & $\mathrm{x}$ & $\mathrm{x}$ & $\mathrm{x}$ & $\mathrm{x}$ & $\mathrm{x}$ & $\mathrm{x}$ & $\mathrm{x}$ & $\mathrm{x}$ & $\mathrm{x}$ \\
\hline Industry F.E. $\times$ Post & $\mathrm{x}$ & $\mathrm{x}$ & $x$ & $x$ & $x$ & $x$ & $x$ & $x$ & $x$ & $x$ \\
\hline
\end{tabular}

Notes: Data for firms in the period 1985-1994. Dependent variables are winsorized at 1\% or 5\% of the empirical distribution (benchmark is $2.5 \%$ ). Robust standard errors are clustered at the business group level and are reported in parentheses. Significance level: *** $p<0.01,{ }^{* *} p<0.05, * p<0.1$. 
Table A.8: Solow productivity

\begin{tabular}{lccc}
\hline \hline & \multicolumn{3}{c}{ Productivity } \\
\cline { 2 - 4 } & $(1)$ & $(2)$ & $(3)$ \\
Direct link $\times$ Transition & 0.018 & -0.084 & -0.079 \\
& $(0.150)$ & $(0.166)$ & $(0.169)$ \\
& & & \\
Direct link $\times$ Democracy & -0.059 & -0.047 & 0.081 \\
& $(0.283)$ & $(0.314)$ & $(0.339)$ \\
& & & \\
Indirect link $\times$ Transition & & $-0.202^{*}$ & $-0.204^{*}$ \\
& & $(0.114)$ & $(0.113)$ \\
Indirect link $\times$ Democracy & & 0.017 & 0.045 \\
& & $(0.209)$ & $(0.220)$ \\
Firms & & & \\
Observations & 99 & 99 & 99 \\
Firm \& time F.E. & 792 & 792 & 792 \\
Industry F.E. $\times$ Post & $\mathrm{x}$ & $\mathrm{x}$ & $\mathrm{x}$ \\
\hline \hline
\end{tabular}

Notes: Data for firms in the period 1985-1994. We calculated productivity using a Solow residual. The mean (standard deviation) of productivity before the plebiscite is 0.028 (1.531). Robust standard errors are clustered at the business group level and are reported in parentheses (88 clusters). Significance level: ${ }^{* *} p<0.01,{ }^{* *} p<0.05,{ }^{*} p<0.1$. 
Table A.9: Links to the regime in 1986

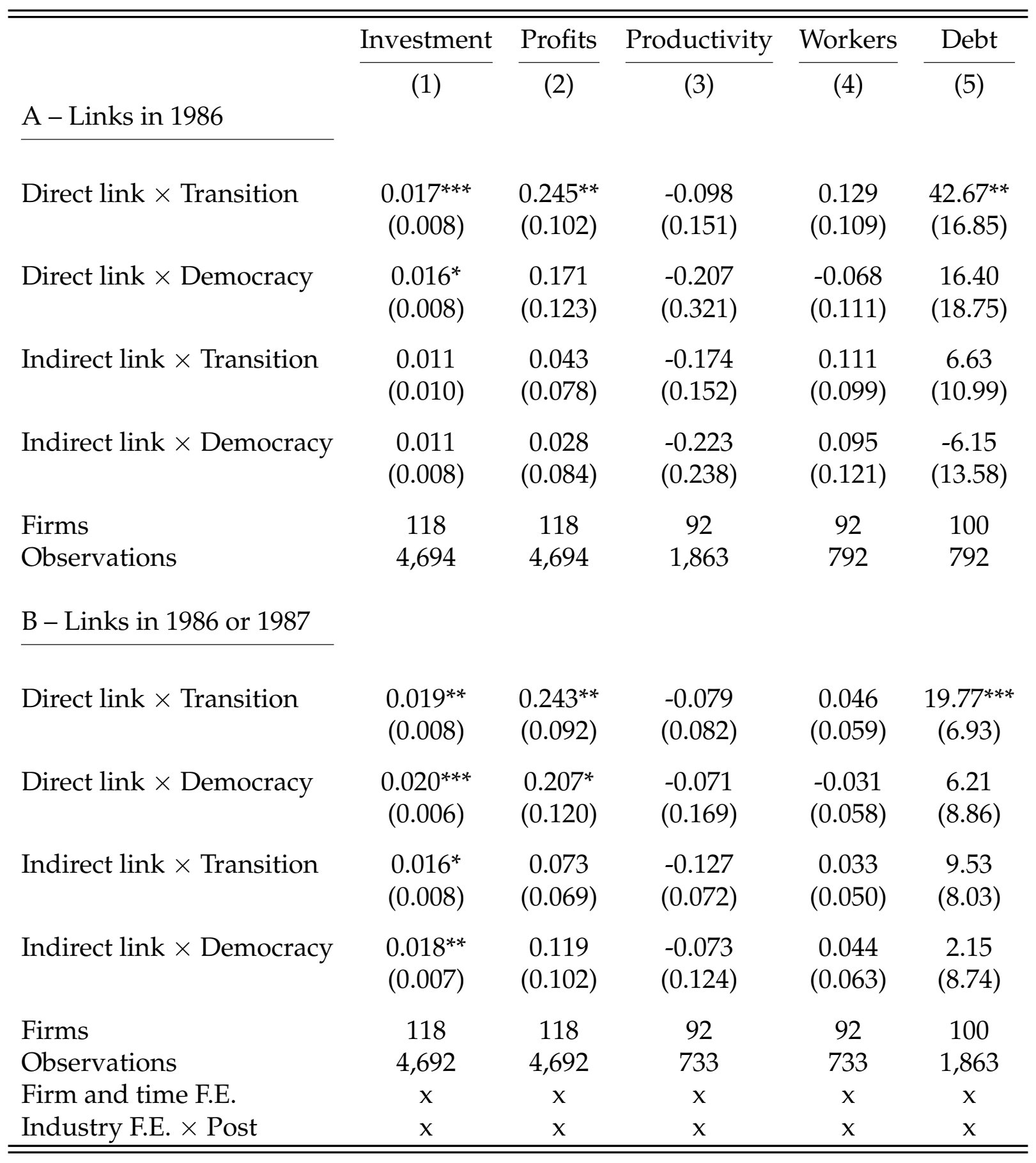

Notes: Data for firms in the period 1985-1994. Robust standard errors are clustered at the business group level and are reported in parentheses. Significance level: ${ }^{* * *} p<0.01$, ${ }^{* *}$ $p<0.05,{ }^{*} p<0.1$. 
Table A.10: Banks with links to the Pinochet regime

Dependent variable is total debt with banks, measured from annual statements

\begin{tabular}{|c|c|c|c|}
\hline & $\begin{array}{c}\text { Bailouts and } \\
\text { Privatizations }\end{array}$ & $\begin{array}{c}\text { Large } \\
\text { Privatizations }\end{array}$ & $\begin{array}{c}\text { Connected } \\
\text { Banks }\end{array}$ \\
\hline & $(1)$ & $(2)$ & (3) \\
\hline Direct link $\times$ Transition $\times$ Banks with links to Pinochet & $\begin{array}{l}38.3^{* *} \\
(17.1)\end{array}$ & $\begin{array}{c}40.1^{* * *} \\
(15.1)\end{array}$ & $\begin{array}{c}37.0^{* * *} \\
(12.9)\end{array}$ \\
\hline Indirect link $\times$ Transition $\times$ Banks with links to Pinochet & $\begin{array}{c}24.5 \\
(20.0)\end{array}$ & $\begin{array}{c}28.9 \\
(19.5)\end{array}$ & $\begin{array}{l}33.5^{*} \\
(18.0)\end{array}$ \\
\hline Double interactions & $x$ & $x$ & $x$ \\
\hline Firm-bank and year F.E. & $x$ & $x$ & $x$ \\
\hline Industry F.E. $\times$ Post & $\mathrm{x}$ & $\mathrm{x}$ & $x$ \\
\hline Mean of dep. variable & 40.3 & 39.4 & 37.6 \\
\hline
\end{tabular}

Notes: Estimation using the annual panel of firms in the period 1985-1994. COLUMN 1: we identify banks with links to Pinochet as state-owned banks and all banks privatized and/or that experienced a bailout during the dictatorship. COLUMN 2: we identify banks with links to Pinochet as state-owned banks and all large banks privatized during the dictatorship (CEME, 2004). COLUMN 3: we identify banks with links to Pinochet as state-owned banks and banks with board members linked to the regime. Robust standard errors are clustered at the business group level and are reported in parentheses (99 clusters). Significance level: ${ }^{* *} p<0.01,{ }^{* *} p<0.05,{ }^{*} p<0.1$. 
Table A.11: Substitution of links from the old to the new regime

\begin{tabular}{|c|c|c|c|c|c|}
\hline A - Control & $\frac{\text { Investment }}{(1)}$ & $\frac{\text { Profits }}{(2)}$ & $\frac{\text { Productivity }}{(3)}$ & $\frac{\text { Workers }}{(4)}$ & $\begin{array}{c}\text { Debt } \\
(5)\end{array}$ \\
\hline Direct link $\times$ Transition & $\begin{array}{l}0.019^{* *} \\
(0.008)\end{array}$ & $\begin{array}{l}0.282^{* *} \\
(0.110)\end{array}$ & $\begin{array}{c}0.016 \\
(0.241)\end{array}$ & $\begin{array}{c}0.074 \\
(0.087)\end{array}$ & $\begin{array}{c}29.77^{* * *} \\
(10.21)\end{array}$ \\
\hline Direct link $\times$ Democracy & $\begin{array}{c}0.021^{* * *} \\
(0.007)\end{array}$ & $\begin{array}{c}0.186 \\
(0.138)\end{array}$ & $\begin{array}{c}0.218 \\
(0.442)\end{array}$ & $\begin{array}{l}-0.006 \\
(0.104)\end{array}$ & $\begin{array}{c}4.45 \\
(14.96)\end{array}$ \\
\hline Indirect link $\times$ Transition & $\begin{array}{c}0.014 \\
(0.009)\end{array}$ & $\begin{array}{l}0.116^{*} \\
(0.068)\end{array}$ & $\begin{array}{l}-0.229^{*} \\
(0.118)\end{array}$ & $\begin{array}{l}-0.003 \\
(0.089)\end{array}$ & $\begin{array}{l}28.41 \\
(20.10)\end{array}$ \\
\hline Indirect link $\times$ Democracy & $\begin{array}{l}0.020^{* *} \\
(0.008)\end{array}$ & $\begin{array}{c}0.149 \\
(0.095)\end{array}$ & $\begin{array}{l}-0.022 \\
(0.229)\end{array}$ & $\begin{array}{c}0.045 \\
(0.110)\end{array}$ & $\begin{array}{l}17.17 \\
(19.47)\end{array}$ \\
\hline Substitution of link $\times$ Post & $\begin{array}{l}-0.006 \\
(0.010)\end{array}$ & $\begin{array}{c}0.053 \\
(0.237)\end{array}$ & $\begin{array}{l}-0.355 \\
(0.431)\end{array}$ & $\begin{array}{l}-0.203 \\
(0.252)\end{array}$ & $\begin{array}{c}15.40 \\
(16.74)\end{array}$ \\
\hline $\begin{array}{l}\text { Firms } \\
\text { Observations }\end{array}$ & $\begin{array}{c}118 \\
4,694\end{array}$ & $\begin{array}{c}118 \\
4,694\end{array}$ & $\begin{array}{c}99 \\
792\end{array}$ & $\begin{array}{c}99 \\
792\end{array}$ & $\begin{array}{c}112 \\
2,073\end{array}$ \\
\hline B - Exclusion & & & & & \\
\hline Direct link $\times$ Transition & $\begin{array}{l}0.016^{*} \\
(0.008)\end{array}$ & $\begin{array}{l}0.291^{* *} \\
(0.119)\end{array}$ & $\begin{array}{l}-0.043 \\
(0.211)\end{array}$ & $\begin{array}{c}0.091 \\
(0.080)\end{array}$ & $\begin{array}{c}30.17^{* * *} \\
(10.29)\end{array}$ \\
\hline Direct link $\times$ Democracy & $\begin{array}{c}0.021^{* * *} \\
(0.007)\end{array}$ & $\begin{array}{c}0.184 \\
(0.137)\end{array}$ & $\begin{array}{c}0.256 \\
(0.463)\end{array}$ & $\begin{array}{l}-0.018 \\
(0.105)\end{array}$ & $\begin{array}{c}6.73 \\
(14.88)\end{array}$ \\
\hline Indirect link $\times$ Transition & $\begin{array}{l}0.016^{*} \\
(0.009)\end{array}$ & $\begin{array}{l}0.161^{* *} \\
(0.069)\end{array}$ & $\begin{array}{l}-0.232 \\
(0.119)\end{array}$ & $\begin{array}{l}-0.002 \\
(0.090)\end{array}$ & $\begin{array}{c}28.39 \\
(20.11)\end{array}$ \\
\hline Indirect link $\times$ Democracy & $\begin{array}{c}0.022^{* * *} \\
(0.008)\end{array}$ & $\begin{array}{l}0.194^{* *} \\
(0.096)\end{array}$ & $\begin{array}{l}-0.023 \\
(0.236)\end{array}$ & $\begin{array}{c}0.047 \\
(0.111)\end{array}$ & $\begin{array}{l}17.16 \\
(19.48)\end{array}$ \\
\hline Firms & 111 & 111 & 92 & 92 & 105 \\
\hline Observations & 4,419 & 4,415 & 725 & 725 & 1,937 \\
\hline Firm and time F.E. & $\mathrm{x}$ & $\mathrm{x}$ & $\mathrm{x}$ & $\mathrm{x}$ & $\mathrm{x}$ \\
\hline Industry F.E. $\times$ Post & $\mathrm{x}$ & $\mathrm{x}$ & $\mathrm{x}$ & $\mathrm{x}$ & $\mathrm{x}$ \\
\hline
\end{tabular}

Notes: Data for firms in the period 1985-1994. Panel A controls for the effect of substituting links and Panel B excludes from estimation the set of firms that substituted links. The "Post" period corresponds to the years after the plebiscite. Robust standard errors are clustered at the business group level and are reported in parentheses. Significance level: *** $p<0.01,{ }^{* *} p<0.05, * p<0.1$. 


\section{Table A.12: Predicting direct and indirect links}

Dependent variable is an indicator for political connections

\begin{tabular}{lccc}
\hline \hline & Direct link & & Indirect link \\
\cline { 2 - 2 } Log assets & $(1)$ & & $(2)$ \\
& $0.186^{* * *}$ & & $0.165^{* * *}$ \\
Privatized & $0.044)$ & & $(0.045)$ \\
& 0.134 & & 0.012 \\
Business group & 0.278 & & $0.637^{* * *}$ \\
& $(0.175)$ & & $(0.116)$ \\
Leverage & $0.140^{* *}$ & $0.217^{*}$ \\
& $(0.059)$ & $(0.122)$ \\
Exporter & -0.192 & -0.006 \\
& $(0.168)$ & $(0.157)$ \\
Age in 1987 & $0.005^{*}$ & $0.005^{*}$ \\
& $(0.003)$ & $(0.002)$ \\
Firms & 85 & 75 \\
\hline \hline
\end{tabular}

Notes: We report marginal effects from cross-sectional probit regressions using indicators for firms with direct and indirect links as dependent variables. Column 1 (2) omits firms with indirect (direct) links. We measure right-hand-side variables as averages in the period 1985-1987. Standard errors in parentheses. Significance level: ${ }^{* *} p<0.01$, ${ }^{* *}$ $p<0.05, * p<0.1$. 
Table A.13: Synthetic controls

\begin{tabular}{|c|c|c|c|c|}
\hline \multirow[b]{3}{*}{ A - Investment } & \multicolumn{2}{|c|}{ Direct link } & \multicolumn{2}{|c|}{ Indirect link } \\
\hline & Unweighted & Weighted & Unweighted & Weighted \\
\hline & & & & \\
\hline Transition & $\begin{array}{c}0.020 \\
{[0.004,0.046]}\end{array}$ & $\begin{array}{c}0.017 \\
{[0.003,0.045]}\end{array}$ & $\begin{array}{c}0.018 \\
{[0.005,0.042]}\end{array}$ & $\begin{array}{c}0.012 \\
{[-0.004,0.040]}\end{array}$ \\
\hline Democracy & $\begin{array}{c}0.000 \\
{[-0.008,0.040]}\end{array}$ & $\begin{array}{c}0.003 \\
{[-0.006,0.041]}\end{array}$ & $\begin{array}{c}0.008 \\
{[-.002, .040]}\end{array}$ & $\begin{array}{c}0.010 \\
{[-0.004,0.057]}\end{array}$ \\
\hline B - Profits & & & & \\
\hline Transition & $\begin{array}{c}0.849 \\
{[0.78,1.89]}\end{array}$ & $\begin{array}{c}0.018 \\
{[0.01,0.56]}\end{array}$ & $\begin{array}{c}0.019 \\
{[-0.13,0.58]}\end{array}$ & $\begin{array}{c}-0.005 \\
{[-0.05,0.46]}\end{array}$ \\
\hline Democracy & $\begin{array}{c}0.425 \\
{[0.11,1.63]}\end{array}$ & $\begin{array}{c}-0.002 \\
{[-0.19,0.45]}\end{array}$ & $\begin{array}{c}-0.073 \\
{[-0.42,0.79]}\end{array}$ & $\begin{array}{c}-0.087 \\
{[-0.21,0.74]}\end{array}$ \\
\hline
\end{tabular}

Notes: Average difference in quarterly investment for firms with direct (indirect) links and synthetic controls. Following Abadie and Gardeazabal (2003) and Abadie et al. (2010), we construct synthetic controls for each firm with a link based on a set of firm characteristics in the period 1985-1987. In particular, we use the logarithm of assets, leverage, and indicators for being part of a business group, being an exporter, and have been privatized by the dictatorship. We present two average differences between firms with links and synthetic controls:

- Unweighted: $M=\frac{1}{N \times T} \sum_{i}^{N} \sum_{t}^{T} I n v_{i t}-I \hat{n} v_{i t}$, where $\hat{I n} v_{i t}=\sum_{j \in \text { Controls }} w_{j}^{i} I n v_{j t}$ and $w_{j}^{i}$ are weights based on the synthetic controls algorithm.

- Weighted: $M w=\sum_{i} \alpha_{i} \times \sum_{t} \frac{I n v_{i t}-I \hat{n} v_{i t}}{T}$ where $a l p h a_{i}=\frac{1 / \sigma_{i}}{\sum_{i} 1 / \sigma_{i}}$ and $\sigma_{i}$ is the goodness of fit of each synthetic control.

To compute confidence intervals, we conduct the following procedure:

1. Generate a bootstrapped sample, $b$, from control group.

2. Estimate $w^{i}$ and compute $M_{b}, M w_{b}$.

3. Repeat the procedure $B=2,000$ times.

4. Compute $[2.5,97.5]$ percentiles of empirical distribution over the bootstrapped sample of $M_{b}$ and $M w_{b}$. These intervals are presented in brackets below the means. 
Table A.14: Entry barriers

Dependent variable is investment

\begin{tabular}{|c|c|c|c|}
\hline & (1) & (2) & (3) \\
\hline Direct link $\times$ Transition $\times$ High entry costs & $\begin{array}{c}0.011 \\
(0.012)\end{array}$ & $\begin{array}{c}0.016 \\
(0.011)\end{array}$ & $\begin{array}{l}0.024^{*} \\
(0.011)\end{array}$ \\
\hline Direct link $\times$ Democracy $\times$ High entry costs & $\begin{array}{c}-0.005 \\
(0.011)\end{array}$ & $\begin{array}{c}0.007 \\
(0.011)\end{array}$ & $\begin{array}{c}0.015 \\
(0.011)\end{array}$ \\
\hline Indirect link $\times$ Transition $\times$ High entry costs & & $\begin{array}{c}0.001 \\
(0.028)\end{array}$ & $\begin{array}{c}0.010 \\
(0.030)\end{array}$ \\
\hline Indirect link $\times$ Democracy $\times$ High entry costs & & $\begin{array}{c}0.020 \\
(0.018)\end{array}$ & $\begin{array}{c}0.029 \\
(0.018)\end{array}$ \\
\hline Direct link $\times$ Transition & $\begin{array}{c}0.002 \\
(0.008)\end{array}$ & $\begin{array}{c}0.005 \\
(0.005)\end{array}$ & $\begin{array}{l}-0.003 \\
(0.009)\end{array}$ \\
\hline Direct link $\times$ Democracy & $\begin{array}{c}0.015 \\
(0.008)\end{array}$ & $\begin{array}{l}0.015^{*} \\
(0.008)\end{array}$ & $\begin{array}{c}0.007 \\
(0.009)\end{array}$ \\
\hline Indirect link $\times$ Transition & & $\begin{array}{c}0.013 \\
(0.026)\end{array}$ & $\begin{array}{c}0.008 \\
(0.029)\end{array}$ \\
\hline Indirect link $\times$ Democracy & & $\begin{array}{c}0.003 \\
(0.015)\end{array}$ & $\begin{array}{c}-0.002 \\
(0.017)\end{array}$ \\
\hline Firms & 118 & 118 & 118 \\
\hline $\begin{array}{l}\text { Observations } \\
\text { Firm and time F.E. }\end{array}$ & $\begin{array}{l}4,694 \\
x\end{array}$ & $\begin{array}{l}4,694 \\
x\end{array}$ & $\begin{array}{l}4,694 \\
x\end{array}$ \\
\hline Industry F.E. $\times$ Post & & & $x$ \\
\hline
\end{tabular}

Notes: Data for firms in the period 1985-1994. To construct industries average sunk cost (i.e. entry costs), we follow ? and take the average of gross book value of property, plant, and equipment in the period 1985-1987. We define "High entry costs" as an indicator for industries with an average sunk cost above the median. Robust standard errors are clustered at the business group level and are reported in parentheses (104 clusters). Significance level: ${ }^{* *} p<0.01,{ }^{* *} p<0.05,{ }^{*} p<0.1$. 
Table A.15: Extraordinary dividends

Dependent variable is payment of extraordinary dividends

\begin{tabular}{|c|c|c|c|c|}
\hline & \multicolumn{2}{|c|}{$\begin{array}{l}\text { Extraordinary } \\
\text { dividends }\end{array}$} & \multicolumn{2}{|c|}{$\begin{array}{l}\text { Payment of } \\
\text { extraordinary } \\
\text { dividends }\end{array}$} \\
\hline & (1) & (2) & (3) & (4) \\
\hline Direct link $\times$ Transition & $\begin{array}{c}0.014 \\
(0.015)\end{array}$ & $\begin{array}{c}0.018 \\
(0.018)\end{array}$ & $\begin{array}{l}-0.090 \\
(0.116)\end{array}$ & $\begin{array}{l}-0.187 \\
(0.136)\end{array}$ \\
\hline Direct link $\times$ Democracy & $\begin{array}{c}-0.041^{* * *} \\
(0.013)\end{array}$ & $\begin{array}{l}-0.030^{*} \\
(0.015)\end{array}$ & $\begin{array}{c}-0.291^{* * *} \\
(0.107)\end{array}$ & $\begin{array}{c}-0.369^{* *} \\
(0.145)\end{array}$ \\
\hline Indirect link $\times$ Transition & & $\begin{array}{c}0.009 \\
(0.015)\end{array}$ & & $\begin{array}{l}-0.208 \\
(0.133)\end{array}$ \\
\hline Indirect link $\times$ Democracy & & $\begin{array}{c}0.021 \\
(0.017)\end{array}$ & & $\begin{array}{l}-0.158 \\
(0.164)\end{array}$ \\
\hline Firms & 72 & 72 & 72 & 72 \\
\hline Observations & 581 & 581 & 581 & 581 \\
\hline Firm and time F.E. & $\mathrm{x}$ & $\mathrm{x}$ & $\mathrm{x}$ & $\mathrm{x}$ \\
\hline Industry F.E. $\times$ Post & $\mathrm{x}$ & $\mathrm{x}$ & $\mathrm{x}$ & $\mathrm{x}$ \\
\hline
\end{tabular}

Notes: Data for firms in the period is 1985-1994. A mandatory dividend of 30\% of earnings is part of the Chilean regulation. The board of the company can decide to pay extraordinary dividends above this threshold. We define "Extraordinary dividends" as payments above the threshold over total assets. Columns 3-4 use an indicator for the payment of extraordinary dividends. Robust standard errors are clustered at the business group level and are reported in parentheses. The number of clusters is 65 . Significance level: ${ }^{* * *}$ $p<0.01,{ }^{* *} p<0.05, * p<0.1$. 